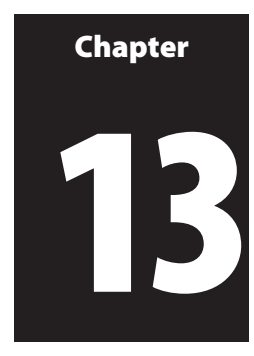

\title{
Red River Hog Potamochoerus porcus (Linnaeus, 1758)
}

Mario Melletti, Thomas Breuer, Brent A. Huffman, Andrea K. Turkalo, Marzia Mirabile, and Fiona Maisels

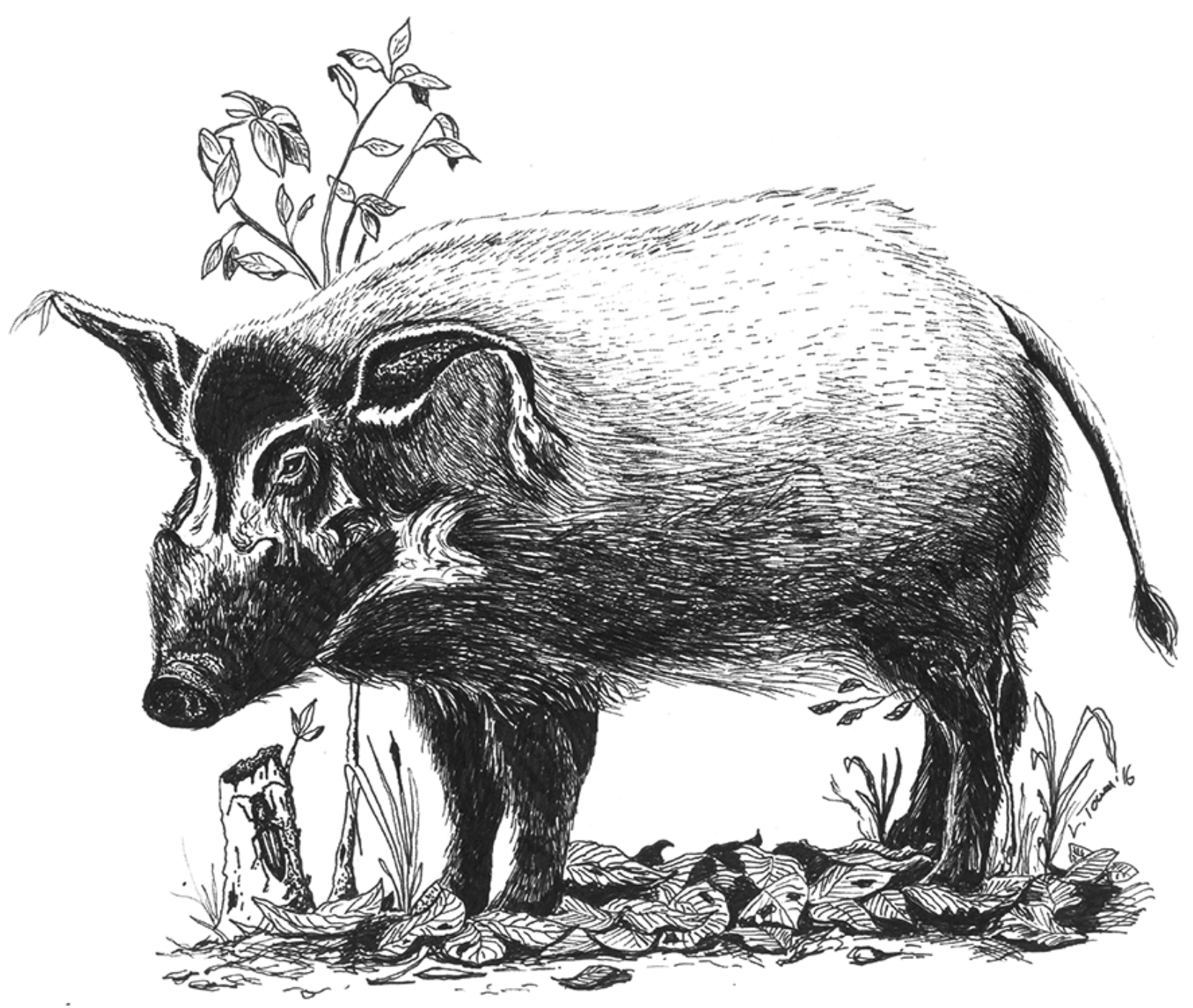

\section{Names}

Genus: Potamochoerus Gray, 1854

Species: Potamochoerus porcus (Linnaeus, 1758)

Names in other languages: French: Potamochère roux, Potamochère d'Afrique; German: Pinselohrschwein; Spanish: Potamocero rojo; Italian: Potamocero rosso, Potamocero di fiume; Afrikaans: Bosvark; kiSwahili: Nguruwe; Lingala in Congo: Ngulu; Lingala in DRC: Nsombo; Teke, Baya: Nguea 


\section{Taxonomy}

The species is monotypic; no subspecies are currently recognized because of the lack of strong morphological differences through its range.

Grubb (1993) and Grubb et al. (1998) stated that the genus Potamochoerus should constitute two species: the red river hog (P. porcus) and the bushpig (P. larvatus). Grubb's work was based mainly on morphological differences and on the fact that the two species show few signs of intergradation or hybridization where their ranges adjoin. However, genetic studies are needed to give a clearer picture about the relations between these two species, particularly in areas of overlap (Kingdon \& Hoffman 2013).

The species has been recorded to interbreed with introduced wild boar, Sus scrofa, in Wonga-Wongue Presidential Hunting Reserve in Gabon (Kingdon \& Hoffman 2013). For more information about the taxonomy of $P$. porcus see Chapter 1 in this book.

\section{Subspecies and Distribution}

The monotypic red river hog occurs mainly in rainforest and gallery forest from Senegal to the eastern regions of the Democratic Republic of Congo (DRC) (Figure 13.1). It has been recorded in almost all of the foot surveys carried out in the forest zone of Central Africa (Cameroon, Central African Republic, Congo, DRC, Equatorial Guinea, and Gabon) and occurs within all of the protected areas in the region surveyed between 2002 and 2016: Table 13.1 shows 88 foot surveys or bai observations across the forest region, and a map of these efforts is shown in Figure 13.2. The southern limit (across most of its range) is the southern edge of the Congo basin rainforest (Leus \& Vercammen 2013). The northern limit appears to be the Sudanian transitional region (Stuart \& Adams 1990), but there has been a contraction of its historical range, particularly in the west and extreme north. In Cameroon, the species is present as far as the north-east of the country, in the woodland and bushy savannas of the Bouda Ndijda National Park and the Niwa hunting area. In the easternmost and southernmost regions of its range, the species is replaced by bushpig, although the range boundary is not well defined (Reyna et al. 2016). There is a possible area of intergradation between red river hog and bushpig in southern DRC and southwest Ethiopia, but information is insufficient for any definitive conclusion (Vercammen et al. 1993). One of the areas of overlap between the bushpig and the red river hog is in the Albertine Rift, where there is an altitudinal separation between them, with the bushpig occurring at higher elevations and the red river hog in lowland forests (Meijaard et al. 2011).

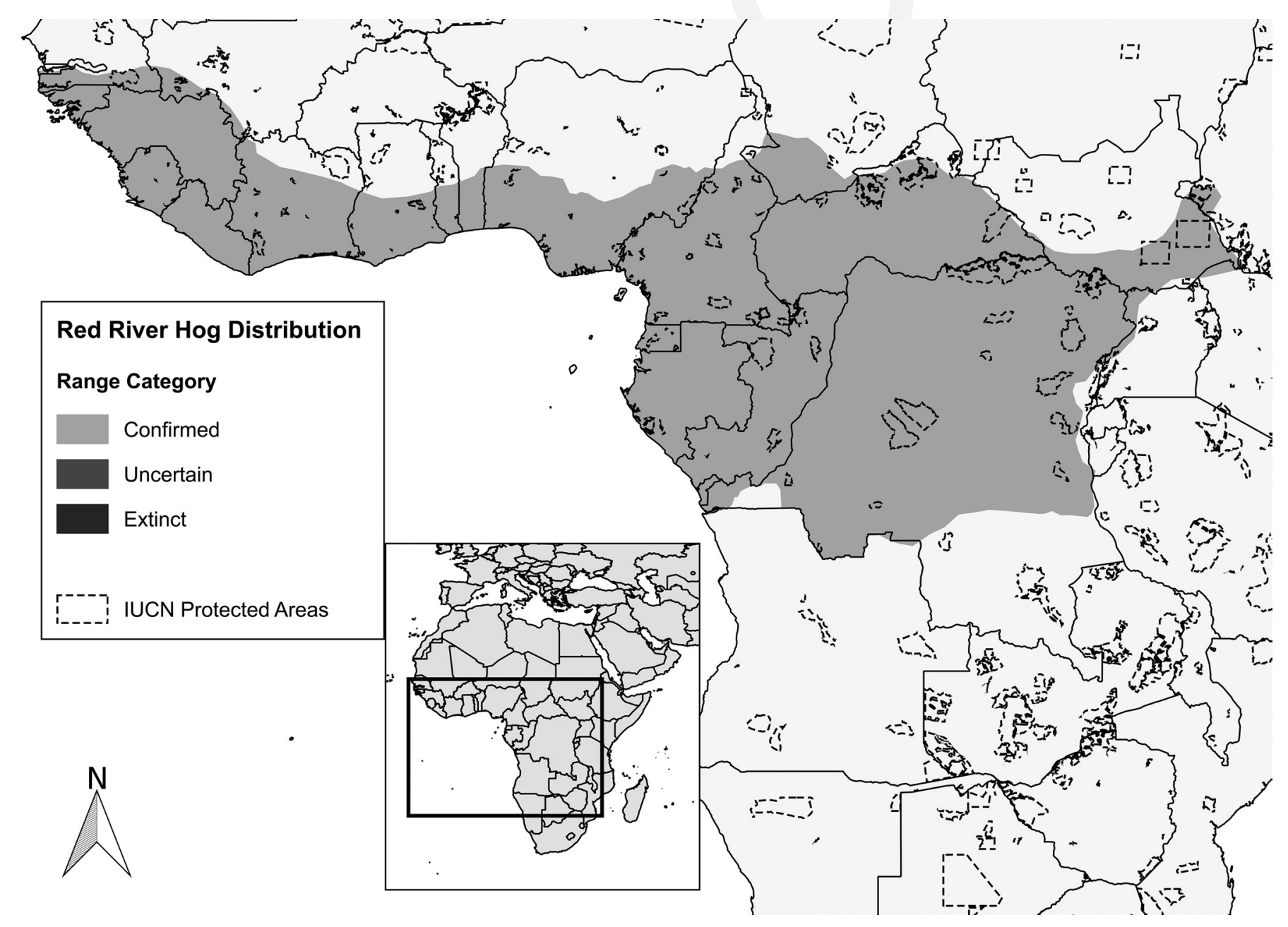

Figure 13.1 Red river hog distribution (source: IUCN 2008, Red List of Threatened Species). 


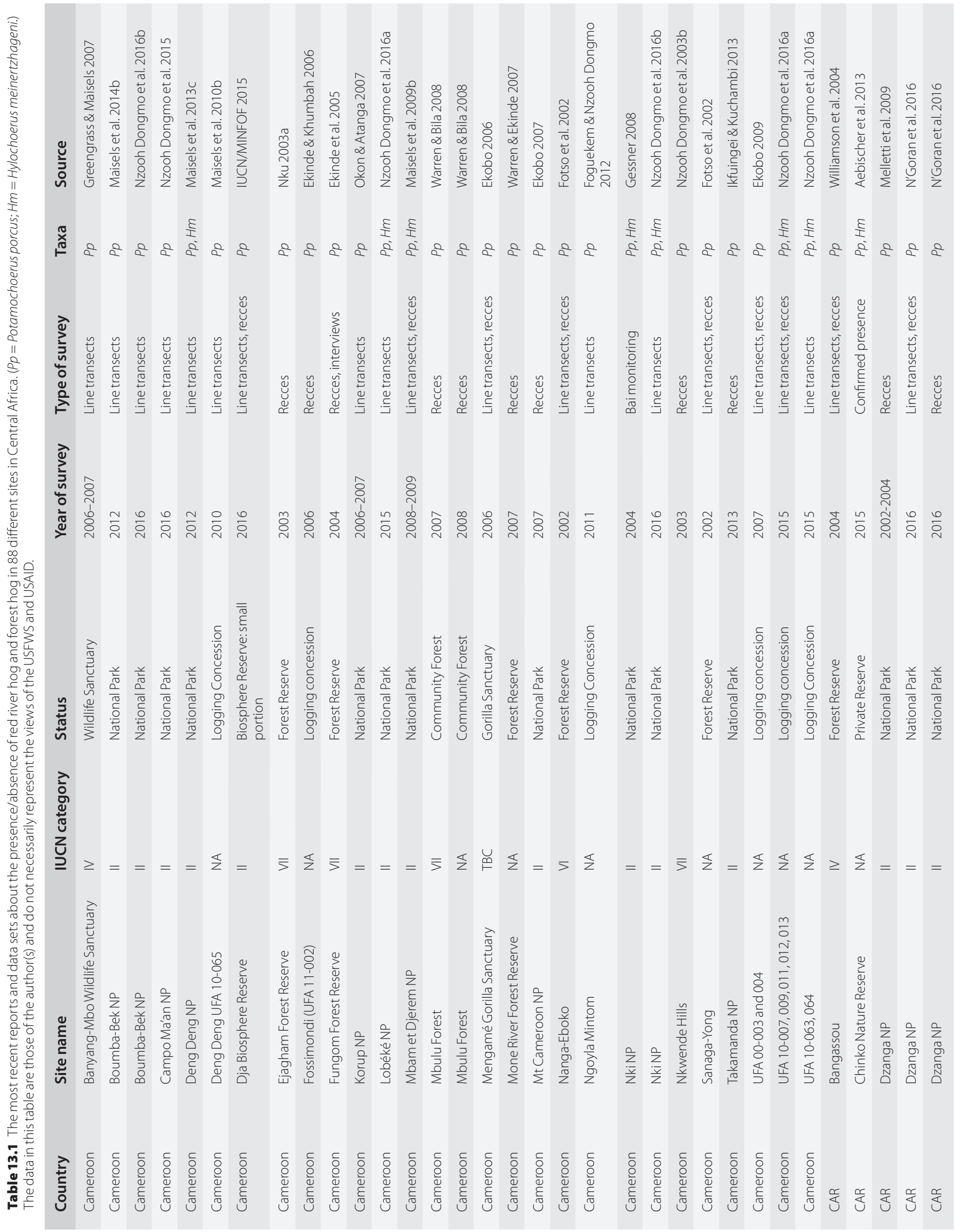




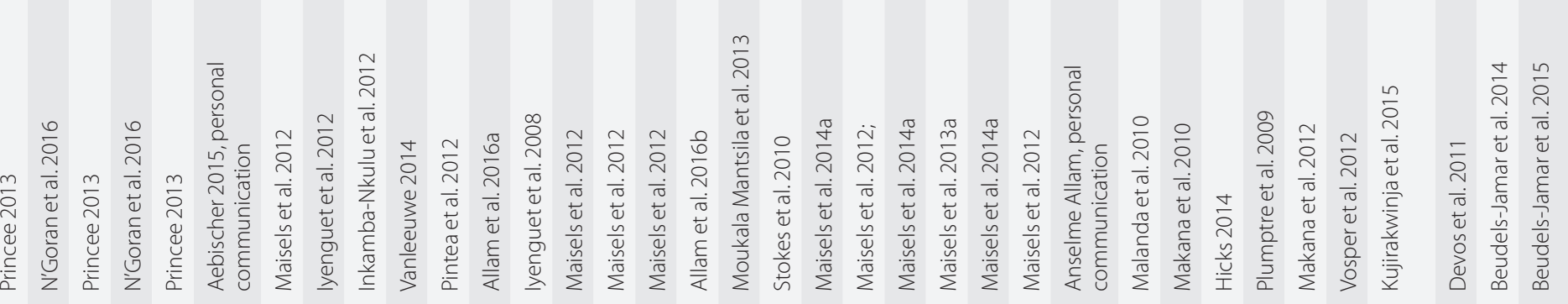

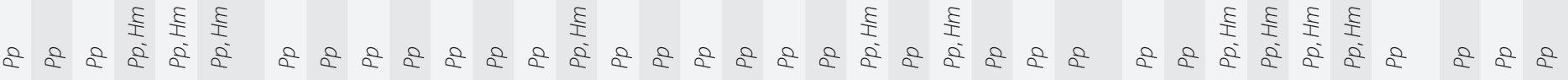

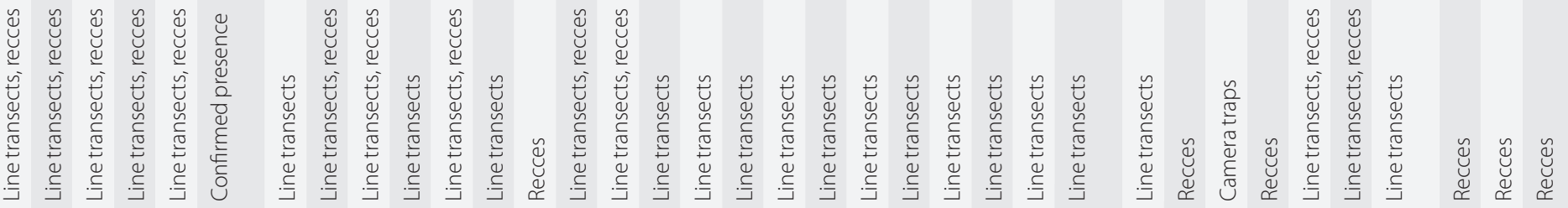

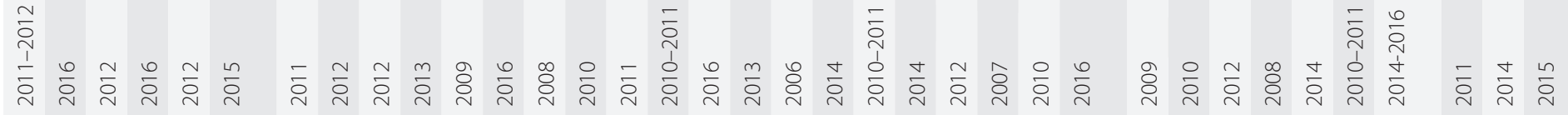

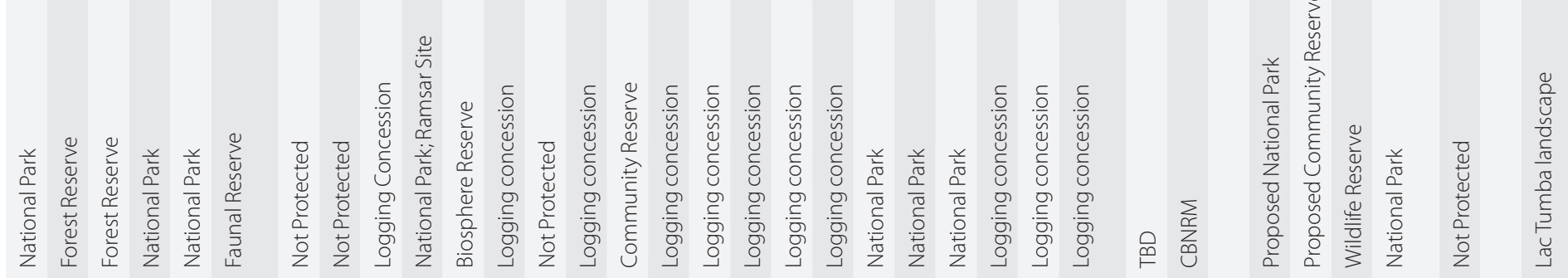

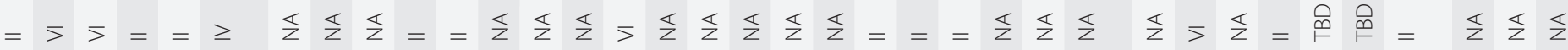

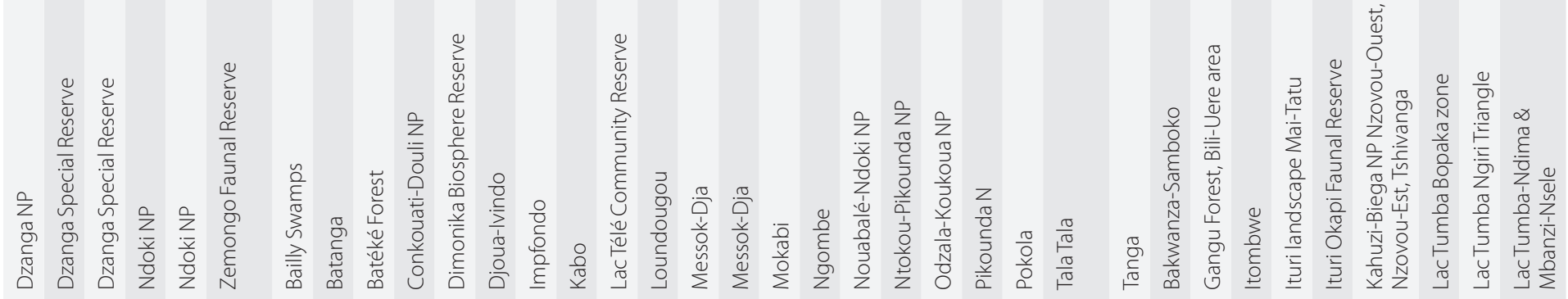

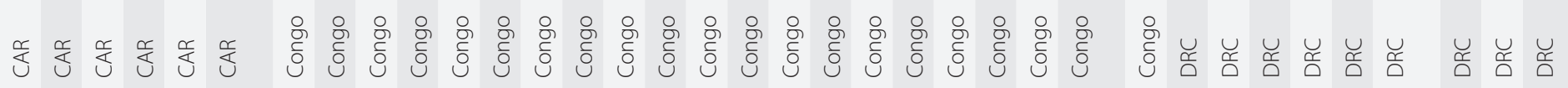




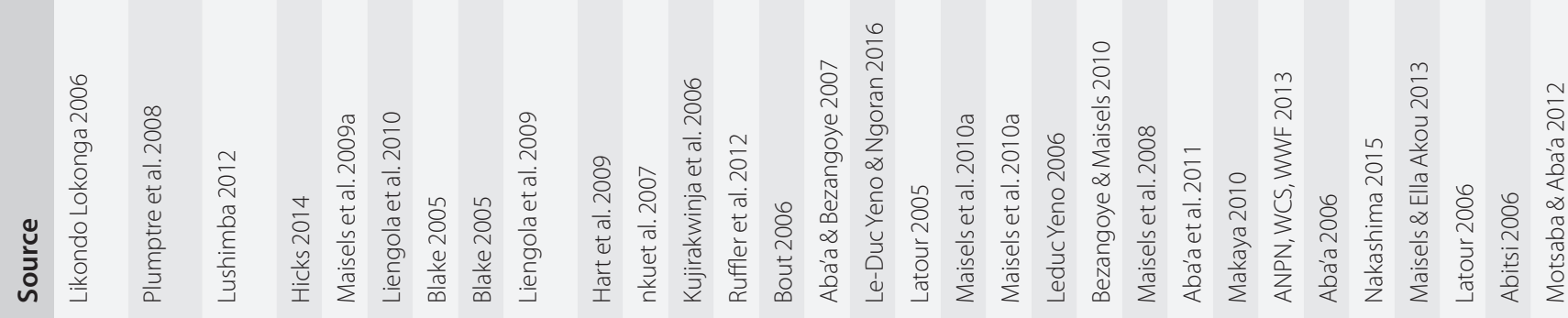

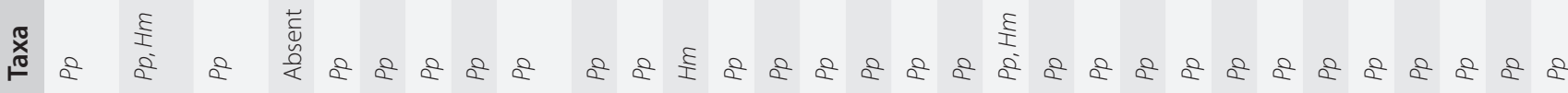

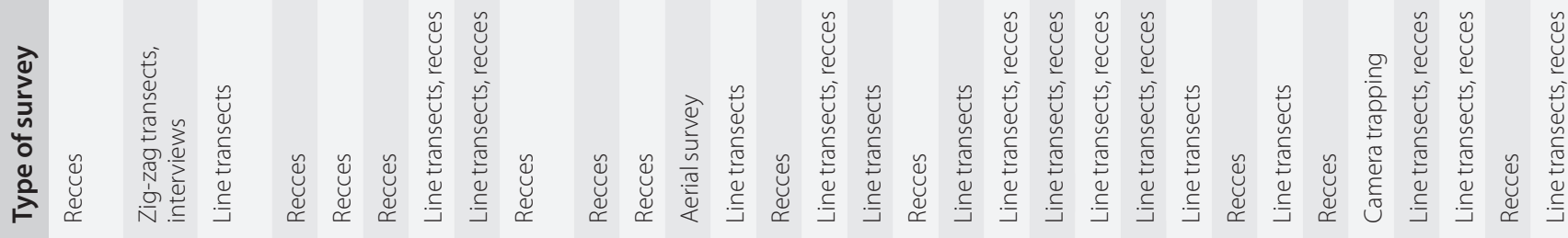

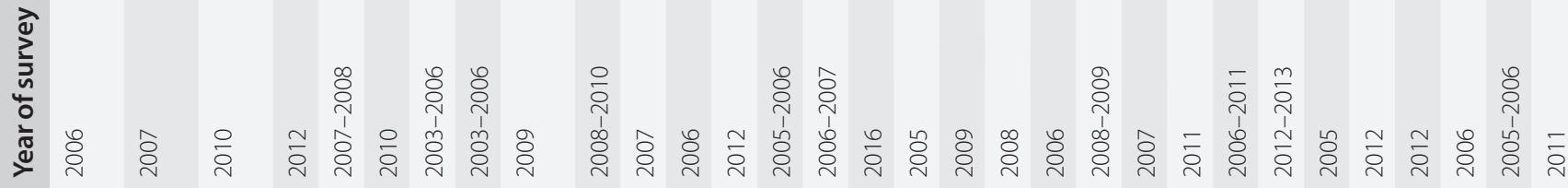

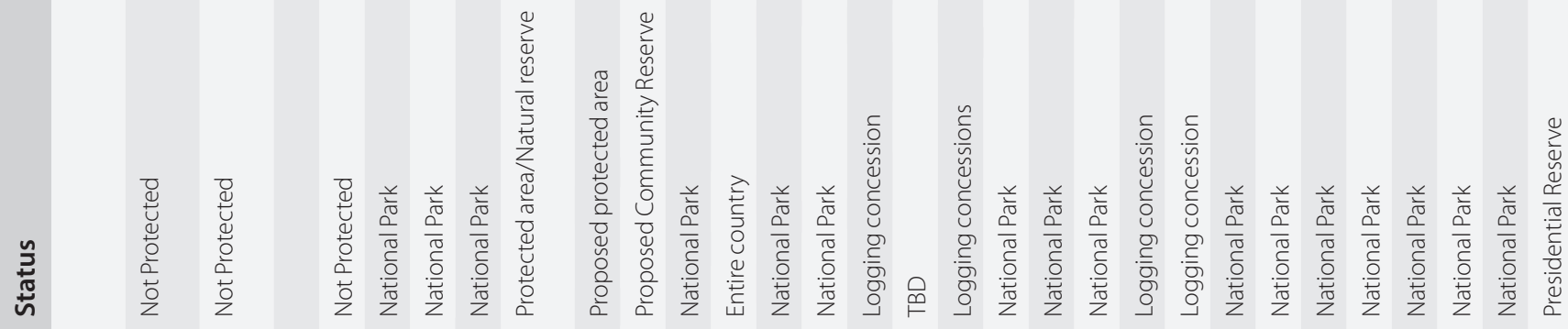

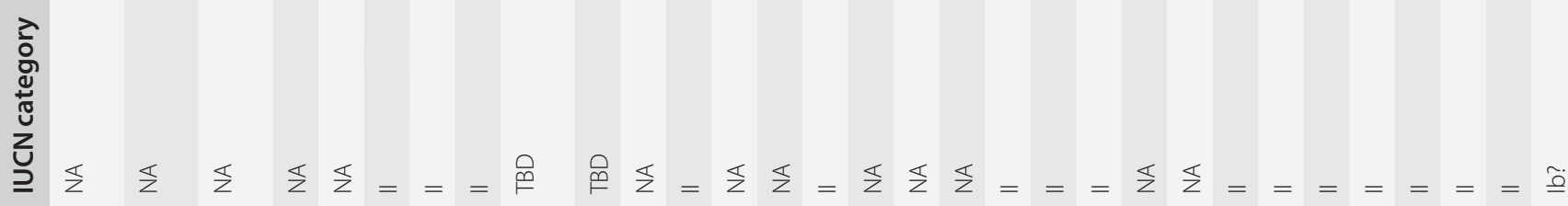

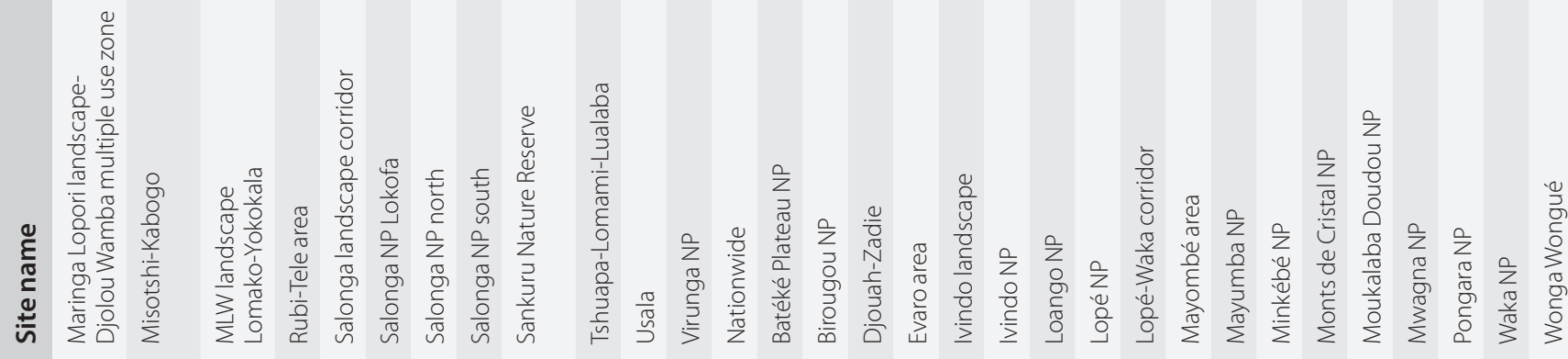

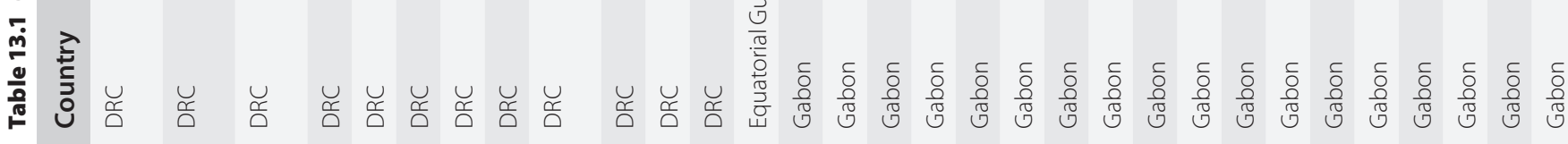




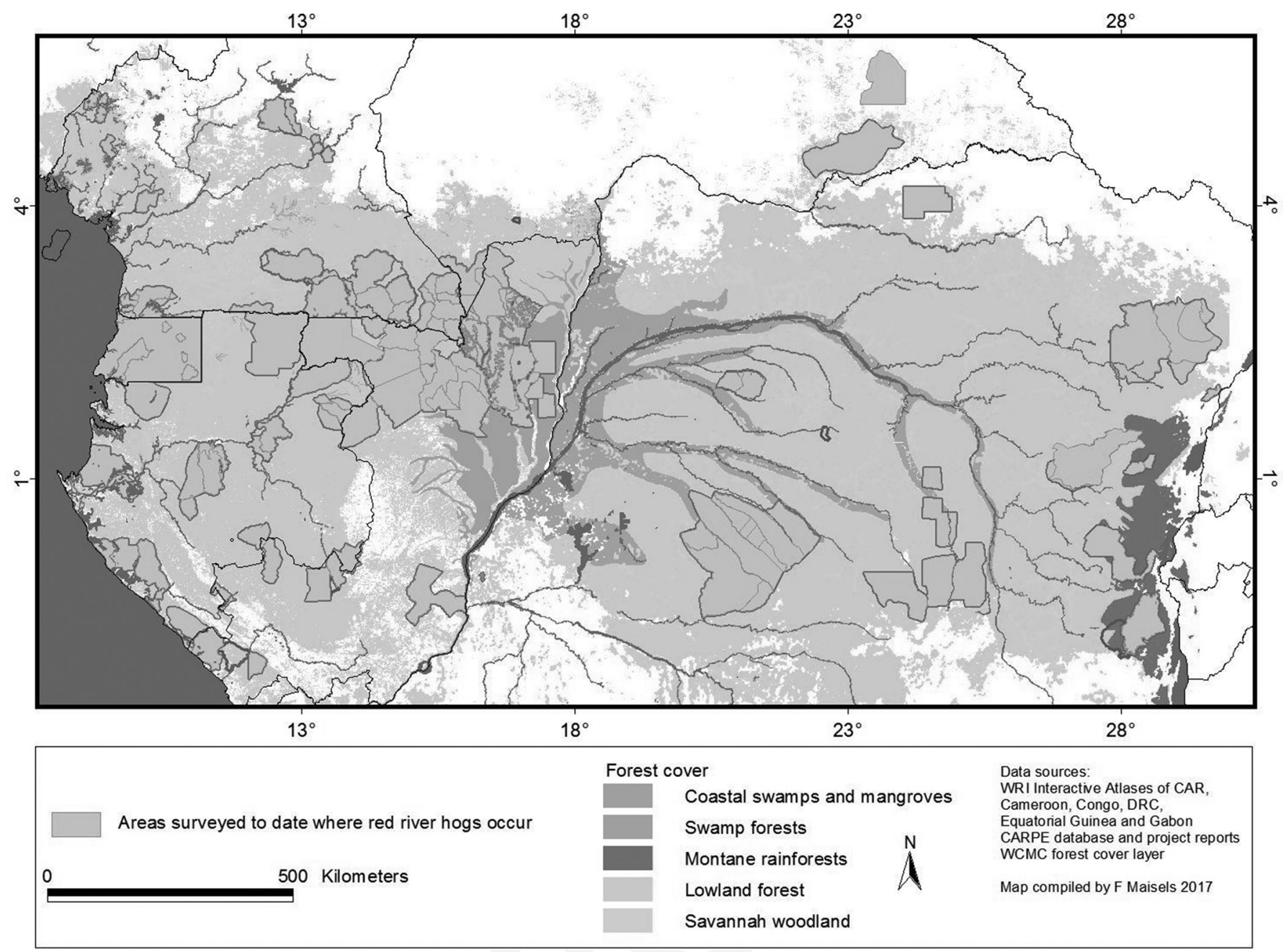

Figure 13.2 Areas surveyed where red river hog occur in Central Africa (see also Table 13.1).

Local discontinuities in distribution in recent years may have been caused by ongoing intensive bushmeat hunting and trade.

The list of countries where the red river hog is considered native includes: Benin, Cabinda (Angola), Cameroon, Central African Republic, Ethiopia Republic of Congo, the Democratic Republic of Congo, Ivory Coast, Equatorial Guinea, Gabon, Gambia, Ghana, Guinea, Guinea-Bissau, Liberia, Mali, Nigeria, Senegal, South Sudan, Togo, and Uganda (Reyna et al. 2016). Red river hogs were recently photographed in southern Sudan (Dasgupta 2015). The presence of this species in southwest Ethiopia and Gambia has not been confirmed (Grubb et al. 1998; Leus \& Vercammen 2013). It occurs in the Cabinda region of northern Angola: although Angola is not mentioned on the Red List page, the Red List distribution map shows this clearly.

\section{Descriptive Notes}

Body measurements: Shoulder height: $55-80 \mathrm{~cm}$; Head and body length: 100-145 cm; Tail length: 30-45; Body mass: 45-115 kg. Dental formula: I 3/3, C 1/1, P 4/3, M 3/3 $(\times 2)=42$. Few measurements of skulls have been recorded: in adult males the skull length varies between 33 and $40 \mathrm{~cm}$ and in adult females between 27 and $38 \mathrm{~cm}$. The number of chromosomes is $2 \mathrm{n}=34$. This species is considered the smallest and most brightly coloured of the African hogs. The pelage is characteristically reddish-orange, and is short and dense, with scattered longer hairs on the flanks. A narrow white dorsal stripe of longer hairs extends from neck to tail and can be erected when the animal is excited. The head is patterned with a grey muzzle and whitish rings around eyes, contrasted by black on the forehead, ears, and jaws (Figure 13.3). In males, long white hairs grow from prominent facial swellings along the jaw and beneath the eyes (Figure 13.4); females do not have these swellings, but often have long white facial hair (Figure 13.5). Adult males develop a pair of protuberances on the side of the muzzle. The canine teeth of males are tusk-like, but as the upper and lower canines rub against each other, they remain short and are usually not visible (Meijaard et al. 2011).The elongated tips of the ears have prominent tufts of white hair. The tail is long and hairless and has a tuft of hair at the tip. Young hogs are dark brown with pale yellow longitudinal marks (Figure 13.5).

Red forms of bushpig (P. larvatus) can be confused with red river hog in areas of overlap, as for example in north-west Uganda where up to four colour morphs have been recorded 


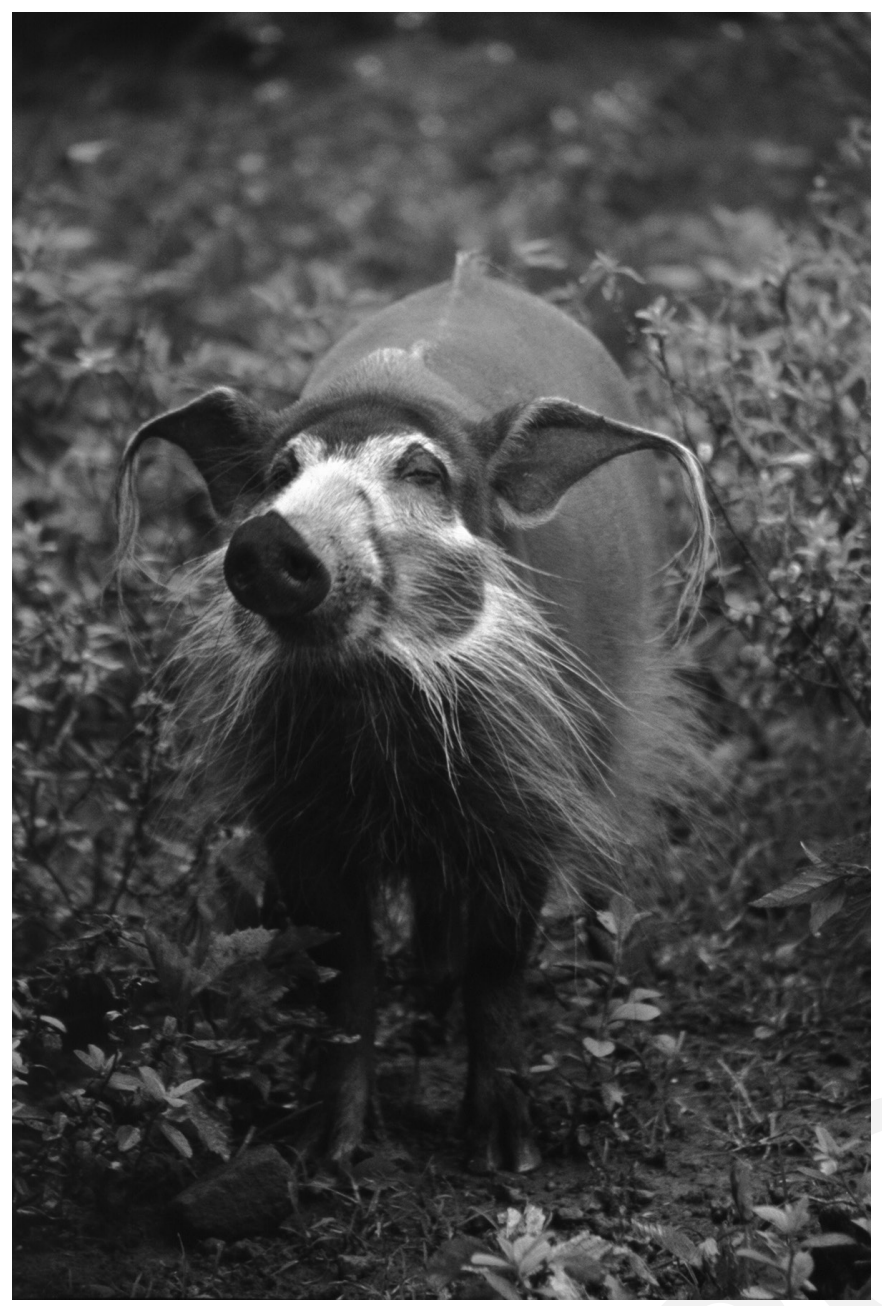

Figure 13.3 Red river hog head and muzzle pattern with a grey muzzle and whitish rings around eyes, contrasted by black on the forehead, ears and jaws (photo by B. A. Huffman).

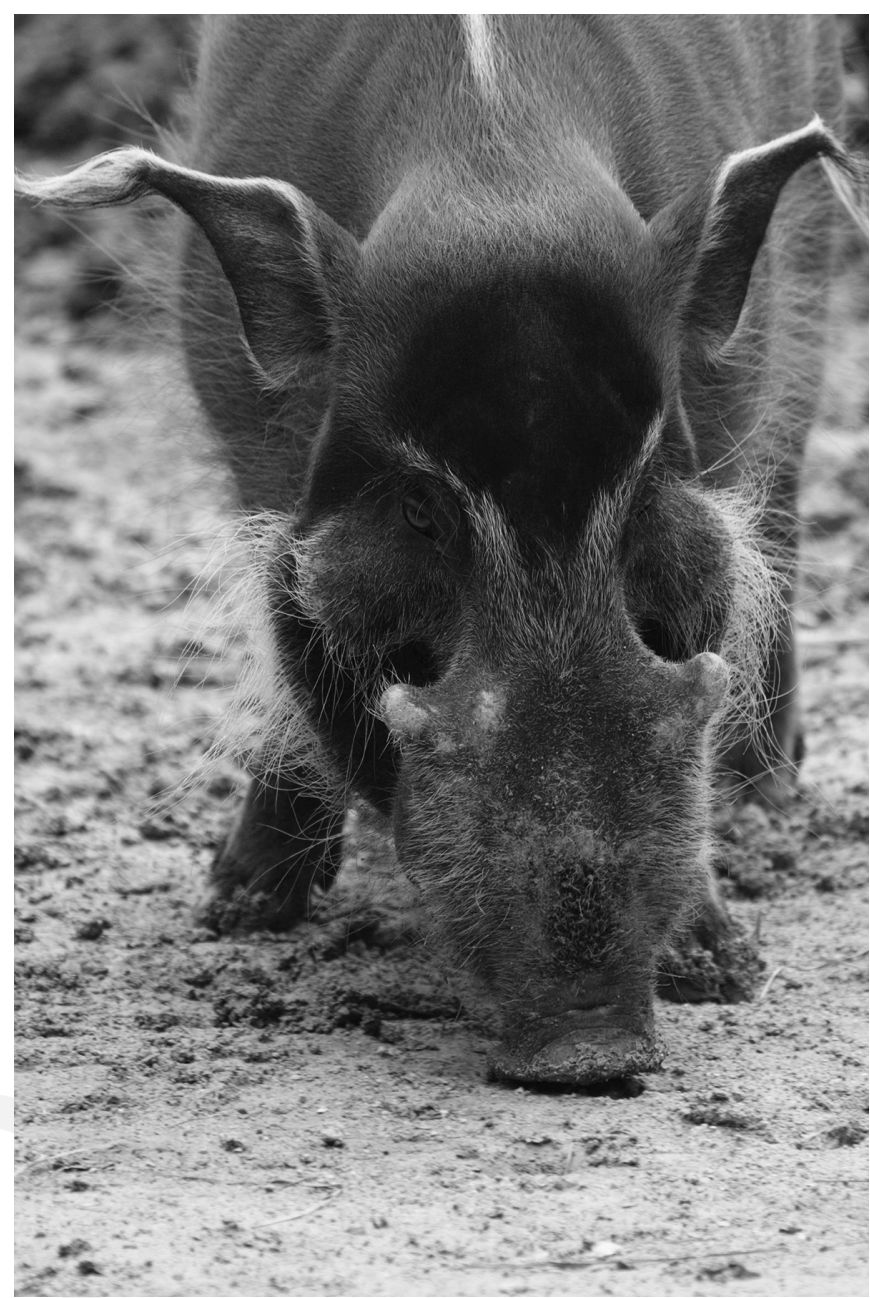

Figure 13.4 Particular of an adult male white hairs grow from prominent facial swellings along the jaw and beneath the eyes (photo by B. A. Huffman).

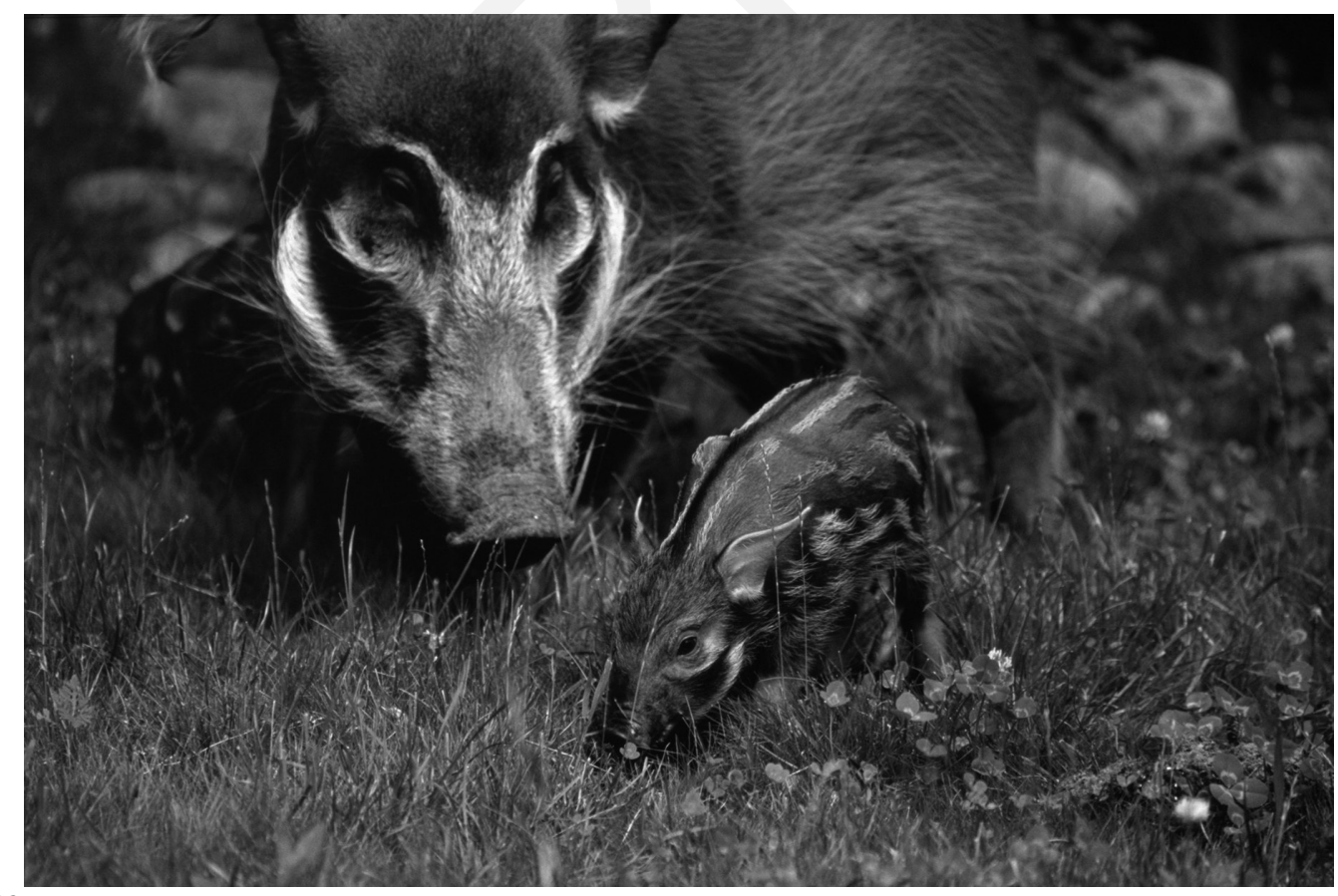

140
Figure 13.5 Particular of female muzzle with long white facial hair and young hog with pale yellow longitudinal marks (photo by B. A. Huffman). 
(Ghiglieri et al. 1982; Seydack 1990, 1991); in these cases the black and white facial markings of $P$. porcus appear diagnostic. Some authors have recorded slight geographic variation in size with the largest animals occurring in East Africa and the smallest ones in the west (Vercammen et al. 1993), although Grubb (1993) did not note any significant variation in size within the species' range.

\section{Habitat}

The red river hog mainly occurs in moist tropical forests with dense cover; however, it is very adaptable and can also be found in secondary rainforest, gallery forest, closed woodland savanna, dry forest, mixed scrub, and cultivated areas. Its sci-

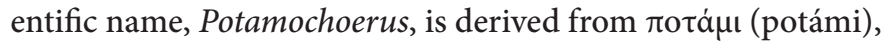
the Greek word for river, and xoipos (choíros), Greek for pig, indicating the species' preference for habitats near water. It is a strong swimmer and frequents swamps and reed beds, although it has been observed in very dense bush at a considerable distance from any large stream (Woodhouse 1911). This species is found throughout the intact old-growth forests of the region, although some authors have found that they appear to favour areas with forest openings and edges where they find a greater diversity of food resources (Oduro 1989; Vercammen et al. 1993; Meijaard et al. 2011; Reyna et al. 2016), possibly related to elephant presence (see below). The species is rarely recorded in open woodland, savanna, or other open habitats unless crossing savanna patches to access forests or woodlands on the other side or to reach isolated forest fragments.

In the Dzanga sector of the Dzanga-Ndoki National Park (Central African Republic), during a two-year study utilizing recce transects (Melletti et al. 2009), red river hogs were encountered in a variety of habitats. Relative use of habitat types appeared to be roughly proportional to their relative coverage in the study area, suggesting no specific habitat preference: this species was primarily recorded in mixed forest, the dominant habitat type ( 72 per cent coverage), but also in Marantaceae forest (18 per cent coverage), monodominant forest of Gilbertiodendron dewevrei (4 per cent), seasonally inundated forest ( 5 per cent), and clearings ( 1 per cent). Similar habitat use, with a preference for mixed closed-canopy forest, was also recorded in Gabon (White 1994; Tutin et al. 1997). The presence of the species in monodominant forest (often with an open understorey) is linked to seasonal peaks in mast fruiting of Gilbertiodendron in the Nouabale-Ndoki and Ituri Forests (Republic of Congo and DRC, respectively) (Blake \& Fay 1997; Hart 2001).

\section{Abundance}

Monitoring rainforest mammals is difficult, as estimates are rarely based on direct observations and often have to rely on proxy signs, such as dung abundance. Because we know very little of average group size and dung decay (Breuer et al. 2010), extrapolations from dung density to pig density are prone to error. Most studies suggest that density normally ranges between 1 and 6 ind. $/ \mathrm{km}^{2}$ but can be much higher on occasion if a superabundant seasonal food resource is available. For example, in Equatorial Guinea, $\mathrm{Fa}$ and Purvis (1997) reported 3.1 ind./ $\mathrm{km}^{2}$. In Lopé National
Park, Gabon, the species can reach 18 ind. $/ \mathrm{km}^{2}$ in the mosaic of equatorial savanna and forest (Tutin et al. 1997), while in forest patches White (1994) recorded 1.3-5.6 ind./ $/ \mathrm{km}^{2}$. In Loango National Park, Gabon, Morgan (2007) found densities of 7.3 ind./ $\mathrm{km}^{2}$. In Ituri Forest (DRC), Hart (2001) reported densities that varied from 0.1 to 8 ind. $/ \mathrm{km}^{2}$ and in other locations densities may be much lower at 1 ind. $/ \mathrm{km}^{2}$ (Kingdon 2013). In Uganda, Laws et al. (1975) estimated the average population density to be 1.29 ind./ $\mathrm{km}^{2}$. Broadly speaking, population density of red river hogs ranges between 0.1 and $18 \mathrm{ind} . / \mathrm{km}^{2}$, with an approximate average of 3 ind. $/ \mathrm{km}^{2}$. Density variation is likely caused by local resource availability and predation pressure, including human hunting.

\section{Movements and Home Range}

There is limited information on the home range and movement patterns of red river hog.

Daily movements may vary considerably depending on habitat type, food resources, and human pressure. Sounders (groups of wild pigs) may travel up to $6 \mathrm{~km}$ within 24 hours as they move between feeding sites and resting places (Meijaard et al. 2011). In Dzanga-Ndoki National Park, Melletti (personal observation) recorded daily movements ranging between 2 and $4 \mathrm{~km}$ in secondary rainforest. In this area, a system of forest clearings was regularly visited on a rotational basis. Moreover, during the mast fruiting of G. dewevrei, daily travel distances of groups in this park were reduced compared to other seasons. Home ranges in the study area varied between 4 and $10 \mathrm{~km}^{2}$ (M. Melletti, personal observation).

\section{Activity Patterns}

Where hunting is absent or highly controlled, red river hogs are very active during the day, so this is most likely the normal behaviour. In areas where hunting pressure is high, red river hogs are primarily nocturnal or remain in areas with dense cover during the day to avoid exposure (Meijaard et al. 2011).

The forests of northern Congo, parts of the Dzanga-Ndoki complex in Central African Republic and and many of Gabon's National Parks are typical of unhunted areas. In Lopé National Park (Gabon), red river hogs can be seen easily during daylight as they cross savannas between forest patches, and they can be encountered in most forest types during the day (Maisels, personal observation). In Langoué Bai (bai is a local word for forest clearing) in the heart of Ivindo National Park in Gabon, and in Mingingi, Mbeli, and Bonye Bais in the Republic of Congo, they are also often visible during daylight. At Mbeli Bai, where observational data have been collected since the early 1990s, daily records of red river hogs range from 06.00 to 16.00 with two peaks: one in the morning and another in the afternoon (Figure 13.6). Within the bai, the hogs used a tiny terra firma portion where they often fed on elephant dung. Human presence at all of these clearings is limited to a spatially predictable site: a tall viewing platform where the observers are located at all times. Human activity within and around these clearings is highly controlled and very rare.

At certain other clearings in the region, red river hogs visit mostly at night. This appears to be the case in the Central African Republic's Dzanga-Sangha complex, and in Cameroon's 

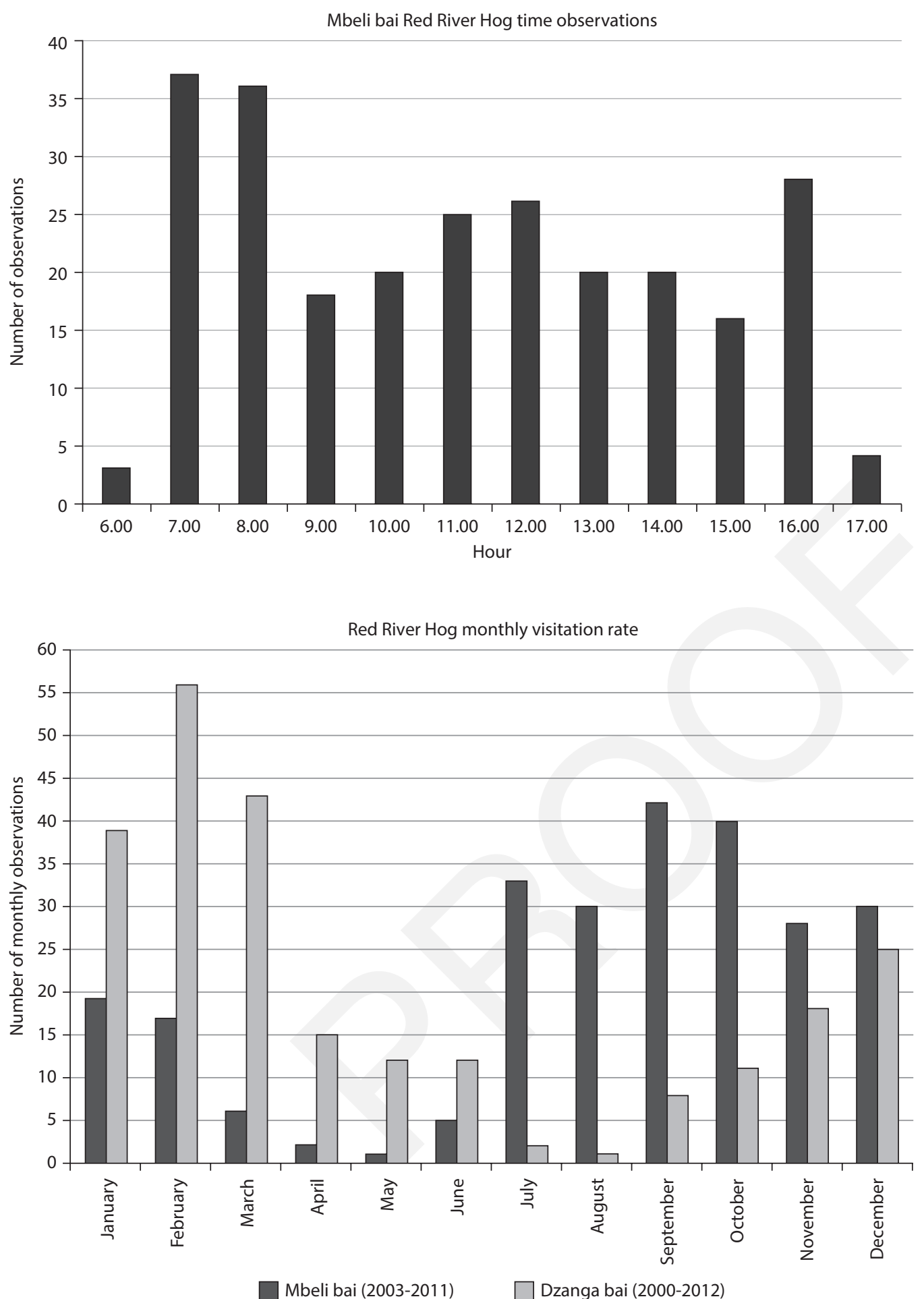

Figure 13.6 Daily observations perhour at Mbeli bai through the year (Nouabalé-Ndoki National Park, Republic of Congo; T. Breuer, unpublished data). Number of observations increased in the morning and in the afternoon.
Figure 13.7 Red river hog monthly observations in Dzanga Bai (2000-2012; Dzanga-Ndoki National Park, Central African Republic; A. Turkalo, unpublished data) and in Mbeli Bai (2003-2011; NouabaléNdoki National Park, Republic of Congo; T. Breuer, unpublished data). Unlike Dzanga where the observations increased between January and March (the dry season), at Mbeli the peaks were observed from September to December (from the wet season to the start of the dry season).
National Parks in the southeast of the country. The very longterm data set (from January 2000 to December 2012; see Figure 13.7) from the Dzanga Bai in the Dzanga-Ndoki National Park (Central African Republic) shows that the species uses the clearing throughout the year, but visits most frequently during the drier months (December-March; A. Turkalo, personal observation). The few daylight observations of red river hogs at this site are generally of single individuals; in con142 meinertzhageni) occur on average five times per week with an average group size of seven individuals (A. Turkalo, personal observation). In two years of field work in the same park, red river hogs were never observed in other forest clearings during daylight hours, although this habitat type was used intensively at night. Occasional sightings during daylight were all in dense cover (Melletti et al. 2009). During a 10-month study at Ikwa Bai, Cameroon, red river hogs visited the clearing only at night (Gessner 2008). It is possible that the clearings had a lower 


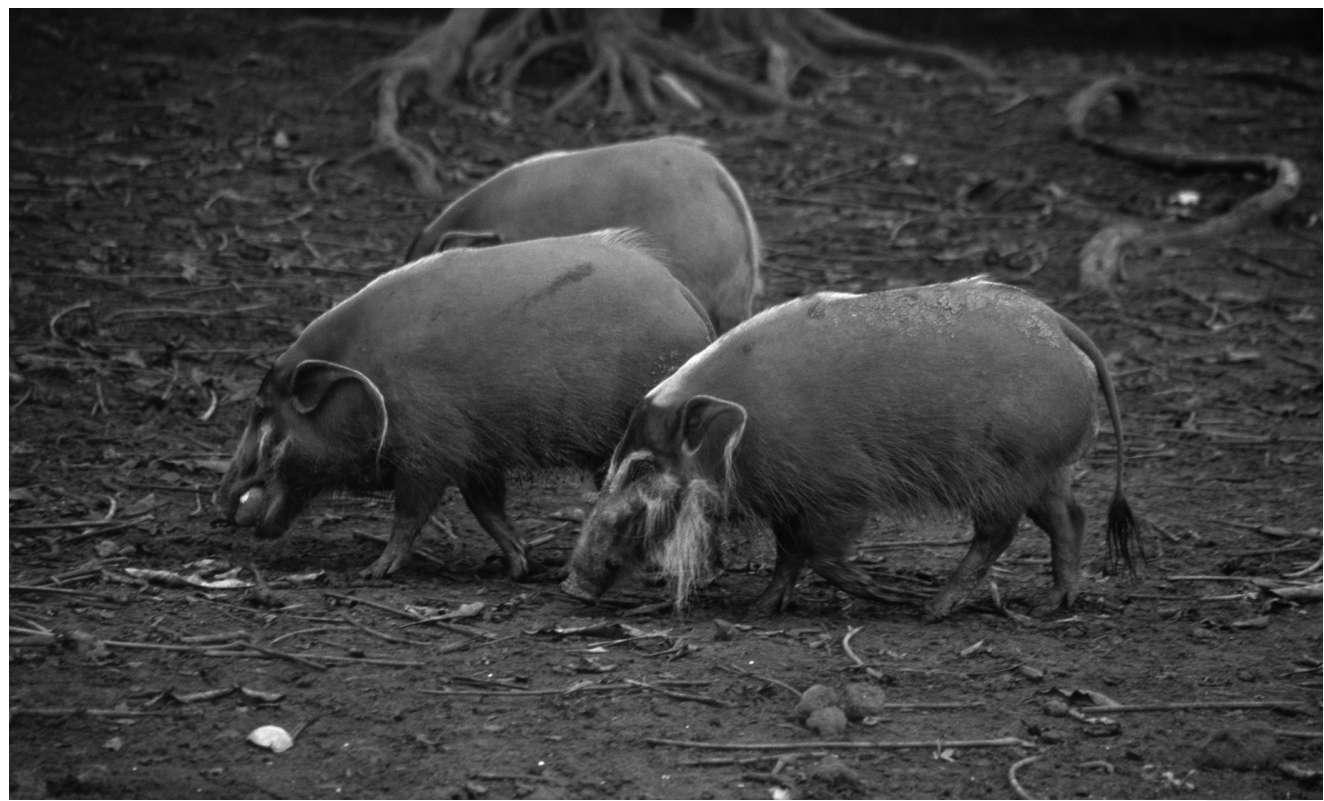

Figure 13.8 A small group of red river hog feeding on fruits (photo by B. A. Huffman).

anti-poaching effort and higher hunting pressure than the clearings in Republic of Congo, or that the pigs perceived any human presence in the forest, including that of researchers, as a danger at these sites.

\section{Feeding Ecology}

This species feeds on a great variety of foods, particularly tubers and roots which are uprooted with the snout, along with seeds gleaned from elephant dung and fruits, grass, aquatic plants, bulbs, fungi, and other seeds (Figure 13.8). Occasionally they will also eat invertebrates, reptiles, eggs and young birds, and carrion. They feed on a wide range of cultivated plants, and in proximity to human settlements they can cause severe damage to crops.

Large groups of red river hogs aggregate seasonally during times of fruit and nut production. Large groups have been observed feeding on the nuts of Coula edulis and Irvingia gabonensis in Gabon (Blake \& Fay 1997; White \& Abernethy 1997; Meijaard et al. 2011) and during the mast fruiting of G. dewevrei in Dzanga-Ndoki National Park. In Dzanga, red river hogs appear to regularly move between forest clearings throughout the year, especially during the dry season (December-April), presumably in reaction to seasonal availability of food resources (M. Melletti, personal observation). In Mbeli Bai, this species is regularly observed around fruit trees (Anonidium mannii, Klainodoxa gabonensis, Chrysophyllum spp.; T. Breuer, personal observation).

During a study of seed predation by red river hogs in LuiKotale research site (Salonga National Park, DRC), the seeds from 26 tree and two liana species were recorded in the diet (see Table 13.2). Based on a 12-ha plot census and a conservative list of seed species eaten, Beaune et al. (2012) estimated that 15.5 per cent of the tree species in the study areas in LuiKotale were seedpredated by red river hogs. Analyses of eight faeces evidenced that none of them contained whole seeds. However, the sample was too small for any conclusion on the degree of seed predation. Studies in other regions have shown that seeds can pass intact through the digestive system of other pig species (Castley et al. 2001; Westcott et al. 2005), which then act as seed dispersers (Kerley et al. 1996). However, the role of red river hog as seed dispersers remains to be determined (Seufert et al. 2010).

Red river hogs regularly forage through elephant dung for seeds (e.g. from Panda oleosa - A. Turkalo, personal observation) and larvae; this food source is especially abundant in bais compared to neighbouring forest and appears to be a major draw for the pigs. Red river hogs will venture into the middle of the clearing seeking dung, unlike giant forest hogs which are observed only along the perimeter. At Mbeli, red river hogs were more frequently observed during the second half of the year, which corresponds with increased elephant activity at that site (Figure 13.7; T. Breuer, personal observation). Red river hogs are also scavengers and have been seen to feed on a baby elephant carcass in Bonye Bai in Republic of Congo (C. Inkamba Nkulu and F. Maisels, personal observations).

\section{Reproduction and Growth}

Very little is known about reproduction of this species in the wild and most information comes from observations in captivity. The gestation period ranges between 120 and 130 days (similar to bushpig, P. larvatus). Parturition appears to be seasonal; neonates have been recorded in February-March in Nigeria and in December-January in Gabon, while in captivity sows can give birth twice a year (Meijaard et al. 2011). The number of piglets may vary between one and six but generally only one or two survive (Vercammen et al. 1993); the mean litter size is 3.4 (Macdonald 2000). During farrowing, sows dig a hollow in the ground and cover it with a nest of grass, leaves, and other vegetation where piglets stay for several days to two weeks, after which they follow their mother. Adult males play an active role in the rearing and defence of the young (Vercammen et al. 1993). Piglets are independent at around 2-4 months, and lose their 
Table 13.2 List of seed species eaten by red river hog in LuiKotale area, Salonga National Park (D. R. Congo), in Dzanga-Ndoki National Park (Central African Republic) and in Nouabalé-Ndoki National Park (Republic of Congo).

\begin{tabular}{|c|c|}
\hline Species & Family \\
\hline Anonidium mannii & Annonaceae \\
\hline Autranella congolensis & Sapotaceae \\
\hline Coula edulis & Olacaceae \\
\hline Colletoecema dewevrei & Rubiaceae \\
\hline Colletoecemasp. & Rubiaceae \\
\hline Crotonogyne manniana & Euphorbiaceae \\
\hline Dacryodes buettneri & Burseraceae \\
\hline Dialium gossweileri & Caesalpiniaceae \\
\hline Dioscorea praehensilis & Dioscoreaceae (liana) \\
\hline Drypetes gossweileri & Euphorbiaceae \\
\hline Gambeya lacourtiana & Sapotaceae \\
\hline Gilbertiodendron dewevrei & Caesalpiniaceae \\
\hline Gilbertiodendron mayombense & Caesalpiniaceae \\
\hline Guibourtia demeusei & Caesalpiniaceae \\
\hline Irvingia gabonensis & Irvingiaceae \\
\hline Irvingia grandifolia & Irvingiaceae \\
\hline Klainodoxagabonensis & Irvingiaceae \\
\hline Lasianthera africana & Rubiaceae \\
\hline Mammea africana & Guttiferae \\
\hline Manilkarayangambiensis & Sapotaceae \\
\hline Panda oleosa & Pandaceae \\
\hline Parinariexcelsa & Chrysobalanaceae \\
\hline Pentaclethra macrophylla & Mimosaceae \\
\hline Pycnanthus marchalianus & Myristicaceae \\
\hline Synsepalum longecuneatum & Sapotaceae \\
\hline Tetracarpidium conophorum & Euphorbiaceae (liana) \\
\hline Treculia africana & Moraceae \\
\hline Tridesmostemon omphalocarpoides & Sapotaceae \\
\hline Vitex sp. & Verbenaceae \\
\hline Xylopia aethiopica & Annonaceae \\
\hline Zeyherella longepedicellata & Sapotaceae \\
\hline
\end{tabular}

neonatal coat pattern at around 6 months (Leus \& Vercammen, 2013). Red river hogs reach adult size at around two years of age, and may reach sexual maturity as early as 18-24 months.

The life span in the wild is estimated at between 8 and 10 years, but may surpass 20 years in captivity (Vercammen et al. 1993; Meijaard et al. 2011).

\section{Behaviour}

As for most pigs, the red river hog is a gregarious species. In Nigeria, group size ranges between 1 and 15 individuals (mean $=$ 10.5 ) with a ratio of immature to adult animals of 2:1 (Oduro 1989). In Dzanga and Mbeli Bais, observed group size ranges 144 single individuals are most common (A. Turkalo and T. Breuer, personal observation; Figure 13.9). In Dzanga, the average group size is 4.9 if one includes single individuals and an average of 10.2 if the single observations are eliminated (A. Turkalo, personal observation; see also Figure 13.9). Much larger groups of up to 60 individuals have been reported from Gabon, Central African Republic, Guinea, and Democratic Republic of Congo (F. Maisels, personal observation (Gabon); Meijaard et al. 2011; M. Melletti, personal observation (Central African Republic); L. Macky and J. Hart, personal communication, respectively). Such large assemblages are believed to be the fusion of more than one group when abundant food resources are available (see Feeding Ecology section for more details); permanent family units are smaller.

Groups are generally composed of multiple adult females, accompanied by subadults, piglets, and one large mature male; groups are mainly sedentary. During moving and feeding, red river hogs emit low grunts to maintain contact and cohesion with other individuals. Adult males may communicate their presence by rubbing and tusking vegetation and soil in a similar way to Eurasian wild boar (Sus scrofa). When two groups meet, ritualized threat displays may occur, but rarely is there serious fighting. Large groups are sometimes followed by flocks of plumed guineafowl (Guttera plumifera) looking for food in the ground rooted by hogs (Meijaard et al. 2011; M. Melletti, personal observation in Dzanga-Ndoki National Park). When wounded and threatened, red river hogs, like other pig species, exhibit considerable courage and will form tight defensive groups or attack predators, including humans. This anti-predator defence has been observed (M. Melletti, personal observation) in Dzanga-Ndoki National Park, where the playback of recorded leopard vocalizations resulted in an aggressive rush of the group towards the sound source. This reaction has been capitalized on by the BaAka people (pygmies), who will imitate a leopard's roar when hunting to bring pigs into closer proximity (M. Melletti, personal observation). Besides significant predation by people, red river hogs are depredated by lion, leopard, spotted hyena, and python. For example, in Lopé National Park, Gabon, red river hog make up 20 per cent of the diet of leopards (Henschel et al. 2005).

\section{Parasites and Diseases}

Very little is known about the ecology and epidemiology of infectious and parasitic diseases in this species.

Red river hogs are reservoirs for some infectious or parasitic diseases, such as trichinosis, African swine fever, and probably trypanosomiases (Anderson et al. 1998). Their role as reservoirs of African Swine Fever can facilitate the dissemination of the virus to domestic pigs (Luther et al. 2007). Every one of 30 carcasses examined in a study in Gabon were infested by around 20 larvae of the nasal botfly Rhinoestrus nivarleti (Payne 2002), and this is apparently common in the region.

\section{Status in the Wild}

Red river hog is listed on the IUCN Red List as Least Concern (Reyna et al. 2016) and is not listed by CITES. The species is still widespread and is locally common in many areas. Across its 


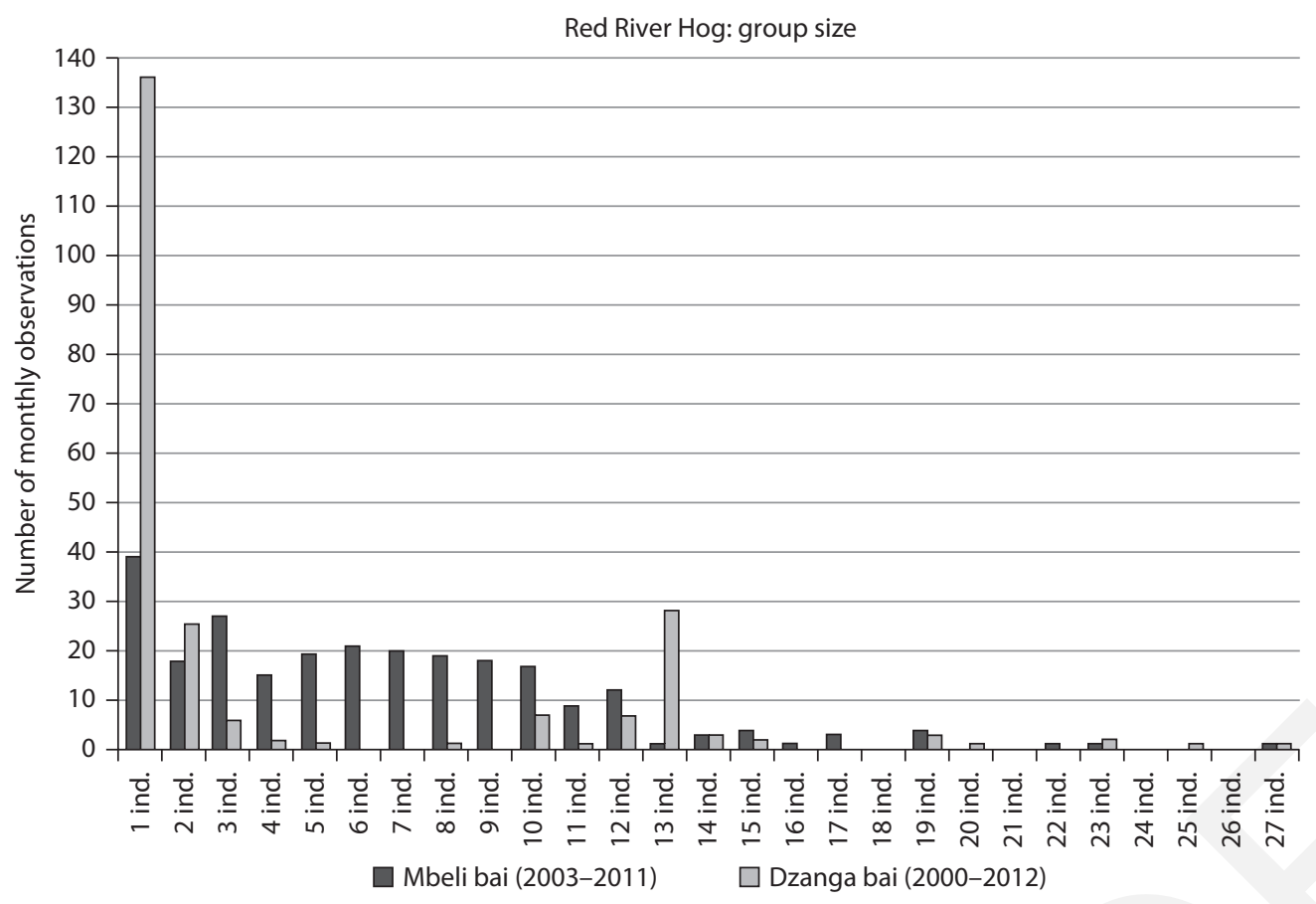

Figure 13.9 Comparison between groups size observed in Dzanga and Mbeli bai (Dzanga-Ndoki National Park, Central African Republic and NouabaléNdoki National Park, Republic of Congo, respectively; A. Turkalo and T. Breuer, unpublished data). In both sites group size ranges from 1 to 27 individuals. range, red river hogs are present, although sometimes very rare, in almost all areas surveyed. However, most surveys have been carried out in protected areas; more work is needed to determine its presence in areas where it is known to be hunted.

The main threat, especially in the Congo Basin, is the bushmeat trade, which is increasing due to growing demand and greater access to forests (Abernethy et al. 2013; Ziegler et al. 2016). Hunters tend to select for medium-sized mammals if they can, especially ungulates and pigs, as they provide a large meat reward for the same effort as a much smaller species. During a study in Gabon, red river hogs, together with duikers, made up between 34 and 37 per cent of the biomass in two urban bushmeat markets of Eastern Gabon (Starkey 2004). In the wild biomass can also be up to $14 \%$, as recorded in the Loango National Park, Gabon (Morgan 2007). However, in more remote, rural areas, they only made up about 7 per cent of the bushmeat eaten (Foerster et al. 2012). Severe population declines were noted as a result of hunting in both northern and coastal Gabon (Lahm 1994; Laurance et al. 2006). Similarly, in northern Congo, red river hogs are a preferred bushmeat species, making up an important proportion of the biomass consumed by local communities (WCS-Nouabalé-Ndoki Project, unpublished data). Furthermore, in the Cross River National Park (Nigeria) and in the south-east of the country, this species remains one of the most hunted and sold in the markets (Angelici et al. 1999; Lameed et al. 2015).

Where red river hogs live near humans, crop predation may lead to persecution by farmers. Such hunting typically fails to eradicate this hog locally because the species avoids active hunting through its nocturnal behaviour (Vercammen et al. 1993).

Although the species is protected in most reserves and national parks in West and Central Africa, the enforcement of such legal protection is challenging and in many cases non-existent.
Deforestation is not considered a real threat to red river hog populations, as the removal of primary-growth forest for timber may increase the availability of preferred secondary growth. However, human activity is often associated with high hunting pressure (Abernethy et al. 2013).

In Burkina Faso, Gabon, and DRC, red river hogs may be threatened genetically by the introduction of Eurasian wild boar, which may also introduce and transmit disease. In these areas, hybrids between these two species have been recorded, although the extent of this hybridization has not been fully described (Vercammen et al. 1993). In other areas, hybridization with feral domestic swine (Sus scrofa) further threatens the species' genetic integrity and health. Addressing this threat is difficult because of the considerable challenge in eradicating feral pigs.

The red river hog remains poorly known and many aspects of its biology, ecology, behaviour, and population status need to be studied. In addition, in some regions populations appear to be in sharp decline due to the bushmeat trade and these populations require much improved protection and management to prevent their extinction (Vercammen et al. 1993; Wilkie \& Carpenter 1999). Finally, genetic studies should be conducted in areas of overlap with the bushpig to resolve the systematic relationships between these two species. Reports exist of polymorphism in some of these overlapping populations and full-genome studies are needed to elucidate levels of gene flow and to draw appropriate taxonomic conclusions.

\section{Status in Captivity}

Red river hogs are kept in many zoological institutions worldwide, mainly for educational purposes. The captive world population, based on 2013-2016 data, includes 177 individuals in 64 North American facilities (Burvenich 2014; see also Chapter 37 for more details), 253 animals in 65 European collections, 21 in 
Asia and seven in African institutions for a global population of 458 individuals (Reiter 2013; see also Chapter 37 for more details; www.species360.org).

\section{Acknowledgements}

The authors are grateful to everyone who provided permission to use data and additional information on the presence of red river hog in Central Africa: Jef Dupain, Nakedi Maputla, Bethan Morgan, Leon Lamprecht, Patrick Darcis, Heidi Ruffler,
Kirstin S. Siex, Torsten Bohm, Cleve Hicks, Jo Thompson, Hilde VanLeeuwe, Thierry Aebischer, Terese Hart, and Andrew Plumptre. Furthermore, we kindly thank the USFWS (US Fish and Wildlife Service) and the American People through the United States Agency for International Development (USAID) contributing to funding a portion of the work that yielded data used in this chapter. The findings and conclusions in this article are those of the author(s) and do not necessarily represent the views of the USFWS and USAID.

\section{References}

Aba'a, R. (2006). Abondance relative des grands mammiferes et des activités humaines au parc National des Monts de Cristal et sa peripherie. Libreville, Gabon: Wildlife Conservation Society, p. 40.

Aba'a, R. \& Bezangoye, A. (2007). Wildlife and human impact monitoring, Birougou National Park, Gabon. Final report. Libreville, Gabon: Wildlife Conservation Society.

Aba'a, R., Maisels, F., Starkey, M. \& Memiaghe, H. R. (2011). Inventaire des grands mammifères et l'impact humaine dans le Mayombe. Activité 3.16 part 1: Rapport Final. Libreville, Gabon: Wildlife Conservation Society, p. 27.

Abernethy, K. A. \& White, L. J. T. (1999). Like living vacuum cleaners, red river hogs give the forest floor a clean sweep. Wildlife Conservation 102: 50-55.

Abernethy, K. A., Coad, L., Taylor, G., Lee, M. E. \& Maisels, F. (2013). Extent and ecological consequences of hunting in Central African rainforests in the twentyfirst century. Philosophical Transactions of the Royal Society B: Biological Sciences 368: 20120303.

Abitsi, G. (2006). Inventaires de reconnaissance des grands mammiferes et de l'impact des activités anthropiques. Parc National de Waka, Gabon. Décembre 2005-Juillet 2006. Libreville, Gabon: Wildlife Conservation Society, p. 38.

Aebischer, T., Hickisch, R., Mararv, E. \& Simpson, D. (2013). The Chinko Project: Sustainable Nature Management in the Chinko/Mbari Drainage Basin, Central African Republic. Online at http:// chinkoproject.com

Allam, A., N'Goran, K. P., Mahoungou, S. \& Ikoa, B. (2016a). Rapport d'inventaire des grands et moyens mammiferes dans la forêt de Djoua-Ivindo. Sembe, République du Congo: WWF GCPO-MEFDD, p. 57.

Allam, A., Beukou, G. B. \& N'Goran, K. P. (2016b). Rapport d'inventaire des grands et moyens mammifères dans la forêt de Messok-Dja. Sembe, République du Congo: WWF GCPO-MEFDD, p. 58.
Anderson, E. C., Hutchings, G. H., Mukarati, N. \& Wilkinson, P. J. (1998). African swine fever virus infection of the bushpig (Potamochoerus porcus) and its significance in the epidemiology of the disease. Veterinary Microbiology 62: 1-15.

Angelici, F. M., Luiselli, L., Politano, E. \& Akani, G. C. (1999). Bushmen and mammal-fauna: a survey of the mammals traded in bush-meat markets of local people in the rainforests of southeastern Nigeria. Anthropologica 30: 51-58.

ANPN, WCS, WWF (2013). Wildlife and poaching assessment in northeast Gabon. Final report. Libreville, Gabon: ANPN, WCS, WWF, USFWS, p. 23

Beaune, D., Bollache, L., Fruth, B. \& Bretagnolle, F. (2012). Bush pig (Potamochoerus porcus) seed predation of bush mango (Irvingia gabonensis) and other plant species in Democratic Republic of Congo. African Journal of Ecology 50: 509-512.

Beudels-Jamar, R., Bankanza, M., Fumutoto, R., et al. (2014). Inventaires faunistiques et botaniques dans la Réserve Naturelle du Triangle de la Ngiri. (du 29/09 au 10/11/2013). Institut Royal des Sciences Naturelles de Belgique/WWF/ ICCN, p. 46.

Beudels-Jamar, R., Lafontaine, R.-M., Robert, H., et al. (2015). Inventaires faunistiques dans la Réserve Naturelle de Tumba-Lediima et dans la zone de Mbanzi/Nsélé (17/03 au 25/04/2014 et 19/08 au 20/09/2014). Institut Royal des Sciences Naturelles de Belgique/WWF/ ICCN, p. 69

Bezangoye, A. \& Maisels, F. (2010). Great ape and human impact monitoring in the Lopé-Waka Exceptional Priority Area, Gabon. Part 1 : Lope National park. GACF Agreement: 98210-8-G529. Final performance report to USFWS. Libreville, Gabon: Wildlife Conservation Society, p. 62 .

Blake, S. (2005). Long term system for monitoring the illegal killing of elephants (MIKE): Central African Forests - final report on population surveys (2003-2004). Washington, DC: CITES-MIKE, p. 122.

Blake, S. \& Fay, J. M. (1997). Seed production by Gilbertiodendron dewevrei in the Nouabale-Ndoki National Park, Congo, and its implications for large mammals. Journal of Tropical Ecology 13: 886-891.

Bout, N. (2006). Suivi écologique des grands mammifères et de la pression humaine. Parc National des Plateaux Batéké. Rapport finale. Libreville, Gabon: Wildlife Conservation Society Gabon /JAF, p. 108.

Breuer, T., Breuer-Ndoundou Hockemba, M. \& Mavinga, F. (2010). Dung decay and its implication for population estimates of duikers (Cephalophus and Philantoba spp.) and red river hogs (Potamochaerus porcus) in the Nouabalé-Ndoki National Park, Republic of Congo. African Jounal of Ecology 48: 551-554.

Burvenich, P. (2014). Red River Hog (Potamochoerus porcus) AZA Regional Studbook., Silver Spring, MD: Association of Zoos and Aquariums.

Castley, J., Bruton, J. S., Kerley, G. \& Mclachlan, A. (2001). The importance of seed dispersal in the Alexandria Coastal Dunefield, South Africa. Journal of Coastal Conservation 7: 57-70.

Dasgupta, S. (2015). 'Forgotten forests' of South Sudan: Camera traps capture first-ever pictures of forest elephants, giant pangolins in the country. Available at: http://news.mongabay.com/2015/12/ forgotten-forests-of-south-sudan-cameratraps-capture-first-ever-pictures-offorest-elephants-giant-pangolins-in-thecountry/. Red river hogs: www.bucknell .edu/x107202.xml.

Devos, C., Ikembelo Beka, B. \& Tshimanga, G. (2011). Inventaires de faune dans le sud du paysage Tumba, RDC : Bloc forestier de Bopaka (novembre 2011). Unpublished report. Projet PICBOU, Composante du Programme Lac Tumba, WWF, Kinshasa, DRC.

Ekinde, A. E. \& Khumbah, P. (2006). Cross River gorilla surveys in south-east UFA 11-002 and search for genetic samples in 
the Besali-Bechati-Fossimondi forests. Limbe, Cameroon: Wildlife Conservation Society, and ERuDeF, p. 27.

Ekinde, A. E., Ashu, M. \& SunderlandGroves, J. (2005). Preliminary ape surveys around the Fungom Forest Reserve and Furu-Awa subdivision, North-West Province, Cameroon. Limbe, Cameroon: Wildlife Conservation Society, p. 45.

Ekobo, A. (2006). Evaluation des potentialites fauniques du Sanctuaire des gorilles a Mengame. Yaounde, Cameroon: WWF, p. 51.

(2007). Surveys of large mammals in the Mount Cameroon forest. Yaounde, Cameroon: WWF Cameroon Coastal Forests Programme, p. 41. (2009). Etude Sur les Potentialités Fauniques des UFAs 11-003 et 11-004 Province du Sud-ouest, Cameroun. Yaounde, Cameroon: WWF, p. 26.

Fa, J. E. \& Purvis, A. (1997). Body size, diet and population density in afrotropical forest mammals: a comparison with neotropical species. Journal of Animal Ecology 66: 98-112.

Foerster, S., Wilkie, D.S., Morelli, G.A., et al. (2012). Correlates of bushmeat hunting among remote rural households in Gabon, Central Africa. Conservation Biology 26: 335-344.

Foguekem, D. \& Nzooh Dongmo, Z. L. (2012). Abundance, distribution of large mammals, and human activities in the Ngoyla-Mintom forest block, Cameroon: implication for land-use planning, management and biodiversity conservation. Yaounde, Cameroon: WWF Cameroon Country Programme Office, p. 66.

Fotso, R., Eno Nku, M. \& Groves, J. (2002). Distribution and conservation status of gorilla population in the forests around Belabo, Eastern Province, Cameroon. Report to Cameroon Oil Transportation Company (COTCO), p. 59.

Gessner, J. (2008). Survey of mammals at Ikwa bai - Nki National Park, south-east Cameroon in terms of conservation and ethology with a focus on the African forest buffalo (Syncerus caffer nanus). Oldenburg: Carl von Ossietsky University, p. 123.

Ghiglieri, M. P., Butynski, T. M., Struhsaker, T. T., et al. (1982). Bush pig (Potamochoerus porcus) polychromatism and ecology in Kibale Forest, Uganda. African Journal of Ecology 20: 231-236.

Greengrass, E. J. \& Maisels, F. (2007). Conservation of the Nigerian-Cameroon chimpanzee P. t. vellerosus (and other mammals) in and around the BanyangMbo Wildlife Sanctuary, South-west Province, Cameroon. Limbe, Cameroon: Wildlife Conservation Society, p. 74 .
Grubb, P. (1993). The Afrotropical suids Phacochoeros, Hylochoeros, and Potamochoerus. In Oliver, W. L. R. (ed.), Pigs, peccaries, and hippos: status survey and conservation action plan. Gland: IUCN (World Conservation Union), pp. 66-75.

Grubb, P., Jones, T. S., Davies, A. G., et al. (1998). Mammals of Ghana, Sierra Leone and The Gambia. Zennor, St Ives: Trendrine Press.

Hart, J. A. (2001). Diversity and abundance in an African forest ungulate community and implications for conservation. In Weber, B., White, L., Vedder, A. \& Naughton-Trees, L. (eds.), African rainforest ecology and conservation. New Haven, CT: Yale University Press.

Hart, T. B., Hart, J A., Dechamps, R., Ataholo, M. \& Fournier, M. (2009). A New Conservation Landscape for Bonobo: Discovery and Conservation of the Tshuapa-Lomami-Lualaba Landscape, in the Democratic Republic of Congo. Final Report on USFWS Assistance Award Agreement \# 982107-G285 Lukuru Wildlife Research Foundation/Tshuapa-Lomami-Lualaba Project, Kinshasa, DRC.

Henschel, P., Abernethy, K. A. \& White, L. J. T. (2005). Leopard food habits in the Lopé National Park, Gabon, Central Africa. African Journal of Ecology 43: 21-28.

Hicks, T. C. (2014). Faunal Diversity and Human Impact in Two Protected Areas of Northern DR Congo: Bili-Uéré and RubiTele January 2014. Unpublished report. Lukuru Wildlife Research Foundation, Kinshasa, DRC.

Ikfuingei, R. \& Kuchambi, E. (2013). The Takamanda National Park - large mammal survey, May-July 2013. Limbe, Cameroon: Wildlife Conservation Society, p. 34.

Inkamba-Nkulu, C., Telfer, P. \& Maisels, F. (2012). Conservation of forest elephants in the Ogooué-Leketi National Park, Republic of Congo (Batéké Plateaux, Congo) Phase III. Interim report. Grant \#. 96200-0-G2S7 African Elephant Fund. Reporting period: 25 August 2010-30 September 2012. Brazzaville, Congo: Wildlife Conservation Society, p. 26.

IUCN/MINFOF. (2015). Caractérisation d'une population de grands et moyens mammifères dans la Reserve de Faune du Dja: Potentiel et menaces. p. 31, Yaoundé, Cameroun.

Iyenguet, F. C., Malanda, G. F., Madzoke, B. \& Twagirashyaka, F. (2008). Recensement et Distribution des Grands Mammifères et Activités Humaines dans la Zone Impfondo. Brazzaville, Congo: Wildlife Conservation Society, p. 55.
Iyenguet, F. C., Madzoke, B., Twagirashyaka, F., et al. (2012). Inventaire des Grands Mammifères et Activités Humaines dans la Batanga, Périphérie est de la Réserve Communautaire du Lac Télé, République $d u$ Congo. Brazzaville, Congo: Wildlife Conservation Society, p. 53.

Kerley, G. I. H., Mclachlan, A. \& Castley, J. G. (1996). Diversity and dynamics of bushpockets in the Alexandria coastal Dunefield, South Africa. Landscape and Urban Planning 34: 255-266.

Kingdon, J. S. \& Hoffmann, M. (eds.). (2013). The mammals of Africa. Amsterdam: Academic Press.

Kujirakwinja, D., Plumptre, A. J., Moyer, D. \& Mushenzi, N. (2006). Recensement aérien des grands mammifères $d u$ Parc National des Virunga. Kinshasa, DRC: ICCN, WCS, USFWS.

Kujirakwinja, D., Kirkby, A., Spira, C., et al. (2015). Inventaire de la Biodiversité dans le Parc National de Kahuzi Biega, République Démocratique du Congo. Secteur de Nzovu-Ouest (basse altitude). In Spira, C., Mitamba, G. M., Kirkby, A., et al. (eds.), Inventaire de la Biodiversité dans le Parc National de Kahuzi Biega, République Démocratique du Congo. Secteurs de Nzovu-Est (basse altitude) et de Tshivanga (haute altitude). Kinshasa, DRC: ICCN/Wildlife Conservation Society, p. 58.

Lahm, S. A. (1994). Diversity, abundance and distribution of game in relation to human predation in northeastern Gabon. New York, NY: Wildlife Conservation Society.

Lameed, G. A., Omifolaji, J. K., Abere, A. S. \& Ilori, S. O. (2015). Hunting intensity on wildlife population in Oban Sector of Cross River National Park. Natural Resources 6: 325-330.

Latour, S. (2005). Inventaire de faune autour des lacs du delta de l'Ogooué. Libreville, Gabon: Wildlife Conservation Society, p. 30. (2006). Recensement des elephants et de grands singes dans le region du parc national de Pongara (Gabon). Libreville, Gabon: WCS/Especes Phares, p. 54.

Laurance, W. F., Croes, B. M., Tchignoumba, L., et al. (2006). Impacts of roads and hunting on Central African rainforest mammals. Conservation Biology 20: 1251-1261.

Laws, R. M., Parker I. S. C. \& Johnstone, R. C. B. (1975). Elephants and their habitats: the ecology of elephants in north Bunyoro. Uganda: Oxford University Press.

Leduc Yeno, S. (2006). Suivi des grands mammifères dans le secteur Sud Parc National de Loango, 12 avril au 08 Septembre 2006. Gamba, Gabon: WWF, p. 39.

Le-Duc Yeno, S. \& N’Goran, K. P. (2016). Rapport de l'inventaire des grands et 
moyens mammifères dans la forêt de Djoua-Zadié. Libreville, Gabon: WWF GCPO, p. 44.

Leus, K. \& Vercammen, P. (2013). Potamochoerus porcus. In Kingdon, J. S. \& Hoffmann, M. (eds.), The mammals of Africa. Amsterdam: Academic Press.

Liengola, I., Vosper, A., Maisels, F., Bonyenge, A. \& Nkumu, P. (2009). Conserving Bonobos in the Last Unexplored Forest of the Democratic Republic of Congo the TshuapaLomami-Lualaba Landscape. Kinshasa, DRC: Wildlife Conservation Society.

Liengola, I., Maisels, F., Nkumu, P. \& Bonyenge, A. (2010). Conserving Bonobos in the Lokofa Block of the Salonga National Park, Democratic Republic of Congo. Report to the Beneficia Foundation. Kinshasa, DRC: Wildlife Conservation Society.

Likondo Lokonga, C. (2006). Abundance and distribution of large mammals and human activities throughout the proposed $4,000 \mathrm{~km}^{2}$ Djolou Wamba multiple use zone (Maringa Lopori landscape). Unpublished report. AWF, Kinshasa, DRC.

Lushimba, A. (2012). Recensements des grands mammifères et d'impacts humains dans la Réserve de Faune de LomakoYokokala. Kinshasa, DRC: AWF.

Luther, N. J., Majiyagbe, K. A., Shamaki, D., et al. (2007). Detection of African swine fever virus genomic DNA in a Nigerian red river hog (Potamochoerus porcus). Veterinary Record 160: 58-59. doi:10.1136/vr.160.2.58.

Macdonald, A. A. (2000). Comparative anatomy, physiology and ecology of pregnancy and lactation in wild pigs: a review. In Nijboer, J., Hatt, J. M., Kaumanns, W., Beijnen, A. \& Gansloßer, U. (eds.), Zoo animal nutrition. Fürth: Filander Verlag, pp. 213-236.

Maisels, F. \& Ella Akou, M. (2013b). Mwagna National Park: Report on WWF survey 2012. Libreville, Gabon: ANPN/WCS/ WWF, p. 14.

Maisels, F., Abitsi, G. \& Bezangoye, A. (2008). Great ape and human impact monitoring in the Lopé-Waka Exceptional Priority Area, Gabon. Part 2: The Lopé-Waka Corridor. GACF Agreement: 98210-7-G289. Final performance report to USFWS. Libreville, Gabon: Wildlife Conservation Society, p. 30.

Maisels, F., Nkumu, P. \& Bonyenge, A. (2009a). Salonga National Park, Democratic Republic of Congo: Terrestrial wildife and human impact monitoring programme. Survey Report - Salonga Corridor. Kinshasa, DRC: Wildlife Conservation Society.
Maisels, F., Ambahe, E., Ambassa, R., Nvemgah Yara, C. \& Fosso, B. (2009b). Great ape and human impact monitoring in the Mbam et Djerem National Park, Cameroon. Final report to USFWS-GACF Agreement 98210-7-G290. Unpublished report. Wildlife Conservation Society, Yaounde, Cameroon.

Maisels, F., Motsaba, P. \& Aba'a, R. (2010a). Final report, second cycle of monitoring in Ivindo National Park and southern buffer zone. Final Report to USFWS-GACF Agreement: 98210-7-G297. Libreville, Gabon: Wildlife Conservation Society, p. 71.

Maisels, F., Ambahe, R., Fosso, B., Puomegne, J.-B. \& Fotso, R. (2010b). Wildlife and human impact surveys of the Deng Deng National Park and UFA 10065. Yaounde, Cameroon: Wildlife Conservation Society.

Maisels, F., Nishihara, T., Strindberg, S., et al. (2012). Great Ape and Human Impact Monitoring Training, Surveys, and Protection in the Ndoki-Likouala Landscape, Republic of Congo. GACF Agreement 96200-9-G247. Final Report. Brazzaville, Congo: Wildlife Conservation Society.

Maisels, F., Strindberg, S., Kiminou, F., et al. (2013a). Wildlife and Human Impact Survey 2012, and monitoring 2005-20082012. Odzala-Kokoua National Park, Republic of Congo. Brazzaville, Congo: Fondation Odzala-Kokoua/Wildlife Conservation Society, p. 48.

Maisels, F., Strindberg, S., Ambahe, R., et al. (2013c). Deng Deng National Park and UFA 10-065, Republic of Cameroon. Wildlife and Human Impact Survey 2012. Yaoundé, Cameroon: Wildlife Conservation Society, p. 37.

Maisels, F., Strindberg, S., Rayden, T., et al. (2014a). Wildlife and human impact survey of the Ngombé Ntokou-Pikounda forest landscape, Republic of Congo. Feb-Oct 2014. Republic of Congo: WCS, p. 71.

Maisels, F., Strindberg, S., Bechem, M. et al. (2014b). Boumba Bek National Park, Republic of Cameroon: Wildlife and Human Impact Survey 2012. Nairobi, Kenya: CITES Monitoring of Illegal Killing of Elephants, p. 64.

Malanda, G., Iyenguet, F. \& Madzoke, B. (2010). Inventaire et Distribution des Grands Mammifères et Activités Humaines dans la Zone Tanga. Brazzaville, Congo: Wildlife Conservation Society, p. 79.

Makana, J. R., Madidi, J., Masselink, J., Vyahavwa, C. \& Mukinzi, J. (2010). Rapport des explorations biologiques dans le Sud de la Zone CBNRM Bakwanza (Bloc Samboko). Brazzaville, Congo: WCS.
Makana, J. R., Madidi, J., Vyahavwa, C., et al. (2012). Preliminary Surveys of Chimpanzees in Eastern Ituri Forest, DRC. Final Report: USFWS Agreement no. 98210-8-G642. Unpublished report. Wildlife Conservation Society, Kinshasa, DRC.

Makaya, Q.P. (2010). Monitoring écologique des grands mammifères terrestres et l'impact anthropique dans le Parc National de Mayumba, Gabon - rapport final. Mayumba, Gabon: Wildlife Conservation Survey.

Meijaard, E., d'Huart, J. P. \& Oliver, W. L. (2011). Family Suidae (pigs). In Wilson, D. E. \& Mittermier, R. A. (eds.), Handbook of the mammals of the world, volume 2, hoofed mammals. Barcelona: Lynx Editions, pp. 248-291.

Melletti, M., Mirabile, M., Penteriani, V. \& Boitani, L. (2009). Habitat use by forest mammals in Dzanga-Ndoki National Park, Central Africa Republic. African Journal of Ecology 47: 797-800.

Morgan, B. J. (2007). Group size, density and biomass of large mammals in the Reserve de Faune du Petit Loango, Gabon. African Journal of Ecology 45: 508-518.

Motsaba, P. \& Abaa, R. (2012). Inventaire préliminaire de grands mammifères et des activités anthropiques à la Réserve Présidentielle de Wonga-Wongué. Libreville, Gabon: Wildlife Conservation Society/Projet GEF PARCS Composante 2, p. 24.

Nakashima, Y. (2015). Inventorying medium- and large-sized mammals in the African lowland rainforest using camera trapping. Tropics 23, 151-164.

N’Goran, K. P., Ndomba, D. L. \& Beukou, G. B. (2016). Rapport de l'inventaire des grands et moyens mammifères dans le segment RCA du paysage Tri-national de la Sangha. Bayanga, République Centrafricaine: WWF RCA-APDS, p. 113.

Nixon, S., Mufabule, K., Eliba, A. \& Manubo Patule, I. (2007). A Prospection Survey of the Usala Forest and Proposed Usala (Community) Gorilla Reserve, Democratic Republic of Congo, March-April 2007. Distribution and Conservation Status of Large Mammals with an emphasis on Grauer's Eastern Gorilla, Gorilla beringei graueri. Unpublished report. The Dian Fossey Gorilla Fund International, UGADEC (Union des Associations de Conservation des Gorilles pour le Développement Communautaire à l'Est de RDC), Tayna Centre for Conservation Biology, North Kivu, DRC, Usala Gorilla Reserve, North Kivu DRC, Kinshasa, DRC.

Nku, E. (2003a). Rapid large mammal assessment of Ejagham Forest Reserve, 
South West Province, Cameroon. Limbe, Cameroon: WCS Cameroon.

Nku, E. M. (2003b). Rapid large mammal assessment of Nkwende Hills Forest Concession (UFA 11-001) \& Upper Banyang Forest Concession (UFA 11-002), South West Province - Cameroon. Limbe, Cameroon: WCS Cameroon, p. 28.

Nzooh Dongmo, Z. L., N'Goran, K. P., Fondja Hendji, C. \& Nkono, J. (2015). Evaluation de la dynamique des populations de grands et moyens mammifères dans le domaine forestier permanent de l'unite technique operationelle Campo Ma’an. Yaoundé, Cameroun: WWF CCPO-MINFOF, p. 103.

Nzooh Dongmo, Z. L., N'Goran, K. P., Ekodeck, H., et al. (2016a). Les populations de grand et moyen mammiferes dans le segment Lobéké du paysage Tri National de la Sangha. Yaounde, Cameroun: MINFOF-WWF CCPO, p. 103.

Nzooh Dongmo, Z. L., N'Goran, K. P., Etoga, G., et al. (2016b). Les populations de grands et moyens mammifères dans le segment Cameroun du Paysage TRIDOM: Forêt de Ngoyla-Mintom, PN Boumba Bek et PN Nki et leurs zones périphériques. Yaounde, Cameroon: WWF CCPOMINFOF, p. 101.

Oduro, W. (1989). Ecology of the red river hog in southern Nigeria. Unpublished $\mathrm{PhD}$ thesis, University of Ibadan, Nigeria.

Okon, D. \& Atanga, E. (2007). Monitoring large mammals and human activities in Korup National Park. Yaounde, Cameroon: WWF Cameroon.

Payne, A. (2002). Gestion de la ressource en viande de brousse au Gabon : exemple du potamochère (Potamochoerus porcus) dans la région de Makokou. France: Ecole Nationale Vétérinaire d’Alfort, p. 154.

Pintea, L., Atencia, R. \& Cox, D. (2012). The status of gorillas in the Dimonika Biosphere Reserve. Gorilla Journal 46: 16-19.

Plumptre, A. J., Kujirakwinja, D., Matunguru, J., et al. (2008). Biodiversity surveys in the Misotshi-Kabogo and Marungu regions of Eastern Democratic Republic of Congo with a focus on chimpanzees. Kampala, Uganda: Wildlife Conservation Society.

Plumptre, A. J., Amsini, F., Kujirakwinja, D., et al. (2009). Itombwe Massif Conservation Project: delimitation and zoning of the Itombwe Natural Reserve for protection of great apes. Final Report for USFWS Project 98210 7- G293. Unpublished report. Wildlife Conservation Society, Kampala, Uganda.

Princee, F. P. G. (2013). Biomonitoring Survey 2011-2012 in Dzanga-Sangha Protected Areas. Unpublished report. World Wide Fund for Nature, Bayanga, Central African Republic.

Reiter, J. (2013). European Endangered Species Programme (EEP) studbook for the red river hog (Potamochoerus porcus pictus) Edition 2012. Amsterdam: European Association of Zoos and Aquariums.

Reyna, R., Jori, F., Querouil, S. \& Leus, K. (2016). Potamochoerus porcus. The IUCN Red List of Threatened Species 2016: e.T41771A44141118.

Ruffler, H., Murai, M. \& Kuhl, H. (2012). A Conservation Survey of Great Apes and Elephants, Rio Muni, Equatorial Guinea. Final report submitted to US Fish and Wildlife Service, p. 55. Conservation International, Arlington, USA.

Seufert, V., Linden, B. \& Fischer, F. (2010). Revealing secondary seed removers: results from camera trapping. African Journal of Ecology 48: 914-922.

Seydack A. H. W. (1990). Ecology of the bushpig (Potamochoerus porcus Linn. 1758) in the Cape Province, South Africa. Unpublished $\mathrm{PhD}$ thesis, University of Stellenbosch, South Africa.

(1991). Monographie des buschschweines (Potamochoerus porcus). Bongo 18: 85-102.

Starkey, M. (2004). Commerce and subsistence: the hunting, sale and consumption of bushmeat in Gabon. Cambridge: University of Cambridge.

Stokes, E. J., Strindberg, S., Bakabana, P. C., et al. (2010). Monitoring great ape and elephant abundance at large spatial scales: measuring effectiveness of a conservation landscape. PLoS ONE 5: e10294.

Stuart, S. N. \& Adams, R. J. (1990). Biodiversity in Sub-Saharan Africa and its Islands. IUCN/SSC Occasional Papers, No. 6. Gland: IUCN.

Tutin, C. E. G., White, L. J. T. \& MackangaMissandzou, A. (1997). The use of rain forest mammals of natural forest fragments in an equatorial African Savanna. Conservation Biology 11(5): 1190-1203.

Vanleeuwe, H. (2014). Ecological Surveys 2005, 2008, 2010 and 2013: Ecological Surveys At Conkouati-Douli National
Park, Republic Of Congo. Brazzaville, Congo: Wildlife Conservation Society Congo, p. 15.

Vercammen, P., Seydack, A. H. W. \& Oliver, W. L. R. (1993). The bush pigs (Potamochoerus larvatus and P. porcus). In Oliver, W. L. R. (ed.), Pigs, peccaries, and hippos: status survey and conservation action plan. Gland: IUCN/SSC Pigs and Peccaries Specialist Group-IUCN/SSC Hippo Specialist Group, pp. 93-101.

Vosper, A., Masselink, J. \& Maisels, F. (2012). WCS RFO Program: Great ape and human impact monitoring in Okapi Faunal Reserve, Democratic Republic of Congo. Final report to USFWS-GACF Agreement 96200-0-G100. Unpublished report. Wildlife Conservation Society, Kinshasa, DRC.

Warren, Y. \& Bila, S. E. (2008). Mbulu Survey. Unpublished report. Wildlife Conservation Society Limbé, Cameroon.

Warren, Y. \& Ekinde, A. (2007). Large Mammal Recce Survey of the Mone Forest Reserve. Limbé, Cameroon: Wildlife Conservation Society, p. 69.

Westcott, D. A., Bentrupperbaumer, J., Bradford, M. G. \& Mckeown, A. (2005). Incorporating patterns of disperser behaviour into models of seed dispersal and its effects on estimated dispersal curves. Oecologia 146: 57-67.

White, L. \& Abernethy, K. (1997). A guide to the vegetation of the Lope Reserve Gabon. New York, NY: Wildlife Conservation Society.

White, L. J. T. (1994). Biomass of rain forest mammals in Lopè Reserve, Gabon. Journal of Animal Ecology 63: 499-512.

Wilkie, D. S. \& Carpenter, J. F. (1999). Bushmeat hunting in the Congo Basin. An assessment of impact and options for mitigation. Biodiversity Conservation 8: 927-945.

Williamson, E. A., Bayogo, R., Guimiyessi, G., et al. (2004). Survey of elephants, Bangassou, Central African Republic: conservation status and human impacts May-June 2004. Unpublished report. WCS/CITES/MIKE, New York.

Woodhouse, C. W. (1911). Some East African pigs. Journal of The East Africa and Uganda Natural History Society 2:40-46.

Ziegler, S., Fa, J. E., Wohlfart, C., et al. (2016). Mapping bushmeat hunting pressure in Central Africa. Biotropica 48: 405-412. 